\title{
It's Not Where You Start, It's How You Finish: Predicting Law School and Bar Success
}

\author{
Aaron N. Taylor \\ AccessLex Institute Center for Legal Education Excellence \\ Jason M. Scott \\ AccessLex Institute Center for Legal Education Excellence \\ Joshua L. Jackson \\ AccessLex Institute Center for Legal Education Excellence
}

\begin{abstract}
In this study, we examine the extent to which academic and student engagement factors explain law school grades and first-time bar exam performance. Applying fixed effects linear and logit modeling, our analysis leverages law student transcript data and responses to the Law School Survey of Student Engagement (LSSSE) among students from a diverse group of 20 law schools to estimate academic performance and odds of bar passage. Most notably, we find that GPA improvement during law school is associated with greater odds of passing the bar exam, particularly among students who struggle the most during the first semester. Furthermore, while we find that LSAT scores and undergraduate GPA are predictive $(p<0.05)$ of both law school performance and bar success (as in previous research), these effects are quite modest. Based on these findings, we propose and discuss several recommendations. These should be helpful to higher education scholars and practitioners, particularly law school deans, administrators, faculty, and academic support staff.
\end{abstract}

Keywords: law school, student engagement, bar passage, academic performance, multilevel modeling

\section{INTRODUCTION}

How does a law school's campus environment impact the academic performance of its students and the first-time bar passage performance of its graduates? Researchers have devoted extensive attention to trying to answer this complicated question, focusing on variables such as undergraduate academic performance (Thomas, 2003), ethnic background (Klein, 1990), and bar preparation methods (Johns, 2016). However, these studies often do not account for various aspects of a law school's climate, such as the faculty's interactions with students and the law school's capacity to assist students with unusually heavy nonacademic burdens. Surely, the environment of a law school impacts the academic performance of students and their eventual performance on the bar exam.

This study - the AccessLex/LSSSE Bar Exam Success Initiative-is the first multi-institutional investigation into the factors that help predict law school academic and first-time bar exam performance. 
Fixed effects linear and logit modeling techniques are used to analyze pre-admission data, law school transcript data, and bar exam performance data for almost 5,000 Spring 2018 and 2019 graduates from 20 law schools that participated in this study. Law School Survey of Student Engagement (LSSSE) response data were also analyzed for a subset of about 2,000 graduates.

Despite a small bump in 2019, first-time bar passage rates have been on the decline for more than a decade (Coe, 2017; Ward, 2018), leaving a growing number of law graduates unable to practice law. In addition, graduates from demographic groups that are already underrepresented in the profession are more likely to not pass the bar exam, a stark trend that intensifies the harmful impacts of the overall declines. This study addresses these concerning dynamics by contributing new insight to our broader understanding of factors that promote academic and bar success. The robust incorporation of student engagement factors, as captured on the LSSSE Survey, renders this study distinct from typical analyses.

In undertaking this study, AccessLex and LSSSE partnered with 20 American Bar Association (ABA)approved law schools to conduct analyses of pre-admission and law school transcript data for 4,722 graduates and LSSSE Survey response data for a subset of 2,025 graduates. We explore the relationships between LSAT score, UGPA, law school academic performance, nineteen student engagement factors, and the ultimate outcome of concern: first-time bar exam performance. In the end, we analyze data encompassing the expanse of the law school experience, from pre-admission to the first bar exam administration post-graduation. The LSSSE response data allow us to capture the impact of student experiences inside of their law schools as well as in their outside lives.

To account for variation between the schools (e.g., differences in grading policies, student characteristics) we employ fixed effects modeling. In addition, we include a robust set of controls such as graduating cohort, race/ethnicity, gender, age, and, where applicable and possible, bar exam jurisdiction.

This study emphasizes that indicators of academic performance and student engagement are valuable at helping to identify the roots of academic difficulty, which in turn helps identify students most at risk of not passing the bar exam. But these factors do not tell the whole story. They supplement but do not replace the professional judgement and expertise of faculty and staff who work with law students every day. Nevertheless, the findings in this report can help focus and guide efforts to develop and implement interventions designed to improve law student academic growth and bar exam preparedness.

This report is structured as follows: Section 1 provides background and introduces the research questions; Section 2 summarizes the extant literature and the theoretical framework guiding the research; Section 3 describes the data sources, sample, variables, and statistical models; Section 4 presents the results of our analyses; and Section 5 offers recommendations rooted in the findings and contextualized by the limitations of the study. Granular information regarding our statistical methods and outputs can be found in a separate online appendix. ${ }^{1}$

All data we analyze represent observations and outcomes that occurred prior to the onset of the COVID19 pandemic, which altered the manners in which legal education and the bar exam are delivered. It is not yet known the extent to which policies implemented in response to the pandemic will supplant previous norms on a long-term basis. This is an important consideration because the applicability of our findings to COVID-era outcomes is uncertain. We are confident, however, that the findings illustrate a relationship between law students and their law schools that will persist through and outlast the pandemic.

\section{BACKGROUND}

The national first-time bar exam passage rate fell roughly 10 percentage points from 2007 to 2018 (Coe, 2017; Ward, 2018). This trend reached its nadir with the July 2018 bar exam, when the national average Multistate Bar Examination (MBE) score was 139.5- the lowest in 34 years (Albanese, 2018). Even more disquieting are persistent racial and ethnic disparities in passage rates. A national assessment of bar passage conducted more than 20 years ago by the Law School Admission Council found a gap of nearly 20 percentage points between White and Hispanic test takers and 30 points between White and Black test takers (Wightman, 1998). More recent data from New York and California show virtually no narrowing of these disparities (National Conference of Bar Examiners, 2019; State Bar of California, 2019). 
The declining pass rates and the demographic disparities have spawned important debates about the purpose, design, and legitimacy of bar exams. Recent developments, such as the ABA's revision of its bar passage accreditation standard (ABA, 2019) and the onset of the COVID-19 pandemic (Angelos et al., 2020), have raised the volume of these debates and indeed the stakes of the exams themselves.

For law graduates, failing the bar exam has negative financial and employment consequences (Bambauer, 2009). Law schools face consequences as well. Low pass rates can negatively impact perceptions of a school's quality and can ultimately jeopardize its enrollment and even its accreditation. As a perceived safeguard, many law schools rely heavily on LSAT scores and UGPAs to make admission decisions (Holmquist et al., 2014; Marks \& Moss, 2016). But overreliance on these metrics ${ }^{2}$ often shuts out historically underrepresented students who, on average, score lower on the LSAT and have lower UGPAs (Haddon \& Post, 2006; Holmquist et al., 2014; Randall, 2006). As a result, law student demographics do not reflect the racial and ethnic diversity of the applicant pools from which those students were selected (AccessLex, 2020). Overreliance on LSAT scores and UGPAs in the law school admission process is a principal driver of the persistent dearth of diversity in the legal profession (ABA, 2019; Rhode, 2015; Taylor, 2019).

Diversity in the legal profession is fundamentally an access to justice issue. Lawyers from underrepresented backgrounds are more likely to represent underserved people and interests (Markovic \& Plickert, 2019; Pratt, 2008). Diversifying the legal profession could also help foster higher levels of belief in the legitimacy of our legal system among traditionally marginalized groups (Pratt, 2008). The need for such civic embrace has taken on greater urgency in light of renewed calls for racial justice and the caustic political environment that has highlighted the glaring precariousness of our democracy.

Fostering diverse and equitable access to the legal profession requires law schools to gather empirical evidence on the extent to which admission factors and elements of the law school experience are predictive of, or otherwise tied to, relevant outcomes, such as academic success and bar exam passage. To that end, our research examines:

- The extent to which LSAT score and UGPA predict law school academic and first-time bar exam performance;

- The extent to which law school academic performance predicts first-time bar exam performance;

- What, if any, student engagement factors are associated with law school academic performance; and

- What, if any, student engagement factors are associated with first-time bar exam performance.

\section{LITERATURE REVIEW}

\section{Student Engagement Theory}

Our work is grounded in theories of student engagement (Astin, 1984; Kuh, 2009; Pascarella, 1980; Tinto, 1975), a holistic concept encompassing "the choices and commitments of students, of individual faculty members, and of entire institutions" (McCormick et al., 2013, p. 55). Student engagement theories assert that the learning environment, coupled with student participation in, and perceptions of, that environment, contribute to learning outcomes. Within the higher education context, student engagement includes not only the classroom experience and other academic components, but also student clubs and organizations, common spaces, such as libraries and student unions, and interactions with administration.

Although postsecondary student engagement research is largely situated in the undergraduate context (Carini et al., 2006; Krause \& Coates, 2008; McCormick et al., 2013; Quaye \& Harper, 2014), studies within law schools are emerging. Similar to the undergraduate studies, the law school iterations link engagement to higher grades, professional development, and overall student satisfaction (Austin et al., 2016; Detwiler, 2011; Florio \& Hoffman, 2012; Law School Survey of Student Engagement, 2012; Silver et al., 2013). Additionally, there is limited but promising research tying student engagement to bar passage. Using items from the LSSSE Survey, Austin et al. (2016) find that students who participate in extra- 
curricular activities that foster law school engagement "perform better in law school and on the bar exam" (p. 23).

Despite the research suggesting the importance of student engagement, studies of explanatory factors of law school grades and bar exam performance typically focus on LSAT score and UGPA. Several find that both factors are predictive of law school academic performance, particularly in the first semester and first year (Marks \& Moss, 2016; Shultz \& Zedeck, 2011; Thomas, 2003). These findings help provide a basis for the intense emphasis of both metrics in law school admission processes (Currier, 2016; Law School Admission Council, 2014; Marks \& Moss, 2016).

Prior research also examines the relationship of LSAT score and UGPA to first-time bar passage. Most of these studies find a positive correlation between LSAT score and bar passage (Austin et al., 2016; Georgakopoulos, 2013; Wightman, 1998). The evidence for UGPA is mixed. Some studies find a weak positive correlation (Wightman, 1998); others find no relationship (Austin et al., 2016; Georgakopoulos, 2013; Trujillo, 2007).

Models that account for academic performance during law school tend to have much greater explanatory power. Overwhelmingly, studies indicate that law school grades are the best predictor of firsttime bar passage (Austin et al., 2016; Farley et al., 2018; Georgakopoulos, 2013; Wightman, 1998). Nonetheless, even when LSAT score, UGPA, and law school grades are considered, much of what impacts bar exam performance remains unexplained.

\section{Input-Environment-Outcome Model}

Astin's (1991) Input-Environment-Outcome (I-E-O) model frames our work, which aims to explain law student outcomes using student characteristics and levels of engagement as the input and the law school setting as the environment. It posits that student outcomes (e.g., learning, the acquisition of skills, the development of professional identities, socialization into disciplinary norms) are functions of two kinds of factors: inputs and environment. Inputs include student demographic characteristics, incoming academic indicators, attributes acquired prior to students' entry into the given educational environment, and elements of the student's life outside of the educational environment.

The I-E-O model structures our understanding of both the factors to be considered and the hypotheses to explore in our analysis. Preparing law students for academic success, the bar exam, and for entry into the legal profession is a collaborative effort, involving the commitment and participation of faculty, administrators, staff, and students. The structure and function of institutional policies and practices are also relevant.

\section{Growth Versus Fixed Mindsets}

Our investigation is also informed by recent developments in educational psychology-most importantly, the distinction between growth mindsets and fixed mindsets (Dweck, 2000; Dweck, 2006; Molden \& Dweck, 2006). Many people believe that capacity to learn is "fixed" or unable to be augmented (Adams-Schoen, 2014). A growing body of research, however, asserts that intelligence and cognitive capacities are flexible and adaptable.

Belief in the notion of fixed intellectual capacities is common among law students (Shapcott et al., 2017). The very structure of legal education and its system of grading and sorting students is rooted in a fixed mindset premise. The first year of law school typically plays an outsized role in determining eligibility for sought-after co-curricular experiences, such as law journal membership. Prestigious and lucrative internships and the jobs that often flow therefrom are typically open only to students who attained high grades early on. Grades in later years are relevant but usually pale in importance to the first year.

But much research asserts that embracing growth mindset thinking - in this context referring to the belief that intelligence (and academic performance) is not fixed and can therefore be improved (Sperling \& Shapcott, 2012, p. 48) - can lead to substantial improvements in student outcomes. In the undergraduate context, several studies have reported that interventions that foster growth mindset thinking in students improve academic performance. In a study by Aronson et al. (2002), 79 undergraduate students were instructed to write letters to middle school students explaining that intelligence can be expanded through 
effort and encouraging them to not be discouraged by obstacles to their learning, the premise of growth mindset thinking. At the beginning of the study, participants were given video lessons about human intelligence and its capacity to increase as a function of learning new information. This was ostensibly to prepare the participants to write to younger students about how they can work hard and increase their intelligence-fostering a growth mindset. Participants were also asked to summarize the growth mindset lessons in speeches to further internalize the lessons on intelligence growth. The study found that the participating college students were more likely to believe in the malleability of intelligence, and in turn more likely to achieve higher grades the next semester.

Similarly, in two studies of seventh graders by Blackwell et al. (2007), the authors found that possessing a growth mindset is predictive of an upward grade trajectory and that interventions aimed at fostering growth mindsets improve academic performance. A study by Aditomo (2015) did not find a direct association between growth mindset and academic achievement, but it did find that students with growth mindsets were better able to "bounce back" and maintain motivation after scoring poorly on a midterm exam.

At the law school level, we found only two mindset studies. Both observed the prevalence of fixed mindsets among law students. A survey of 100 first-year law students by Sperling and Shapcott (2012) found that 25 percent had a fixed mindset, 25 percent had a growth mindset, and 50 percent fell somewhere in the middle. Another survey by Shapcott et al. (2017) found that among 425 students across all years, mindsets became more fixed as the students progressed through law school, a seemingly logical trend. There is an absence of research on the impact of growth mindsets on law student outcomes. The findings we present in this report help fill this gap in knowledge.

\section{METHODS}

\section{Data}

The AccessLex/LSSSE Bar Exam Success Initiative is a collaborative effort to understand the relationships between academic and student engagement and bar exam performance. AccessLex and LSSSE partnered with 20 ABA-approved law schools to conduct analyses of pre-admission and law school transcript data for 4,722 graduates and LSSSE Survey responses for a subset of 2,025 graduates who responded to that questionnaire. We explore the relationships between LSAT score, UGPA, law school academic performance, 19 student engagement factors, and the ultimate outcome of concern: first-time bar exam performance. In the end, we analyze data encompassing the expanse of the law school experience, from pre-admission to the first bar exam administration post-graduation. The LSSSE response data allow us to capture the impact of student experiences inside of their law schools as well as in their outside lives.

\section{Pre-Admission and Law School Transcript Data}

Pre-admission and law school transcript data were provided by 20 participating law schools for the 4,722 graduates who: (1) earned a J.D. in 2018 or 2019; (2) were enrolled full-time at graduation; (3) took the bar exam for the first time during the administration immediately following graduation; and (4) took the bar exam in a jurisdiction where at least 25 percent of graduates took the bar exam during the same administration. For each graduate, these data include LSAT score, cumulative UGPA, first-semester (1S) LGPA, first-year (1L) LGPA, second-year (2L) LGPA, final LGPA, class rank, first-time bar result and jurisdiction, race, gender, and birth year. All participating schools secured the necessary internal approvals (e.g., IRB) prior to providing the research team with data.

\section{LSSSE Survey Data}

Survey response data were provided by LSSSE for the 2,025 graduates who completed the questionnaire in their final semester of study. Responses were matched to each graduate's pre-admission and law school transcript data. Analyses were then conducted on the combined dataset with the identities of students and schools removed. 
The LSSSE Survey is the most comprehensive and long-standing effort to measure the impact of legal education on law students and uses student engagement as its conceptual premise. The concept of student engagement is multifaceted and not always directly measurable. LSSSE operationalizes the different facets of the concept using proxy measures and pointed survey items. The survey contains approximately 125 questions and takes 15-20 minutes to complete (LSSSE, 2020). Survey questions explore various facets of how students spend their time inside and outside of the classroom, how they assess their own learning and development, and how they view their law school experiences overall.

Participation is voluntary; thus, LSSSE respondents comprise a convenience sample of law students willing and able to respond to the survey. Some participating schools offer financial incentives or prizes to encourage higher survey completion among students. Since 2004, the LSSSE Survey has been administered to over 380,000 law students at 203 law schools in the U.S., Canada, and Australia. LSSSE's breadth of subject matter and its sheer volume of collected responses render the survey uniquely valuable as a legal education assessment and research tool (LSSSE, 2020).

\section{Sample}

AccessLex offered the opportunity to participate in this study to all ABA-approved law schools. In order to be eligible, schools agreed to:

- Administer the LSSSE Survey in two consecutive years: either academic years 2017-2018 (AY 2017) and 2018-2019 (AY 2018) or AY 2018 and 2019-2020 (AY 2019);

- Share demographic and academic background information for bar-takers in the two LSSSE administration years with AccessLex and LSSSE researchers; and

- Allow aggregate and (anonymized) school-level data to be used in the building of a clearinghouse of relevant information, as well as in reports, presentations, etc.

In order to encourage participation among schools with lower bar pass rates, AccessLex offered a subsidy to cover the LSSSE registration fee to law schools with cumulative first-time bar passage rates below 75 percent in at least two of the previous three calendar years leading up to the study.

Twenty-one (21) schools elected to participate. Of these, one school was excluded from this analysis due to its data being incomparable to the rest of the sample. After this exclusion, our sample consists of pre-admission and law school transcript data for 4,722 graduates from the remaining 20 law schools. Eighteen schools provided data for both AY 2017 and AY 2018, one for only AY 2017, and one for only AY 2018. Table A.II.1 lists each school's number of observations, response rate, and status of participation in the two years of the study. For each school, analyses were conducted on bar exam results only for jurisdictions where at least 25 percent of graduates took the exam.

LSSSE Survey data were received for 2,025 graduates (42.9 percent of the full sample) from the remaining 20 schools. Of these schools, 17 administered LSSSE in both AY 2017-2018 and AY 20182019, two in AY 2017-2018 only, and one in AY 2018-2019 only. 
FIGURE 1

FLOW CHART OF OBSERVATIONS

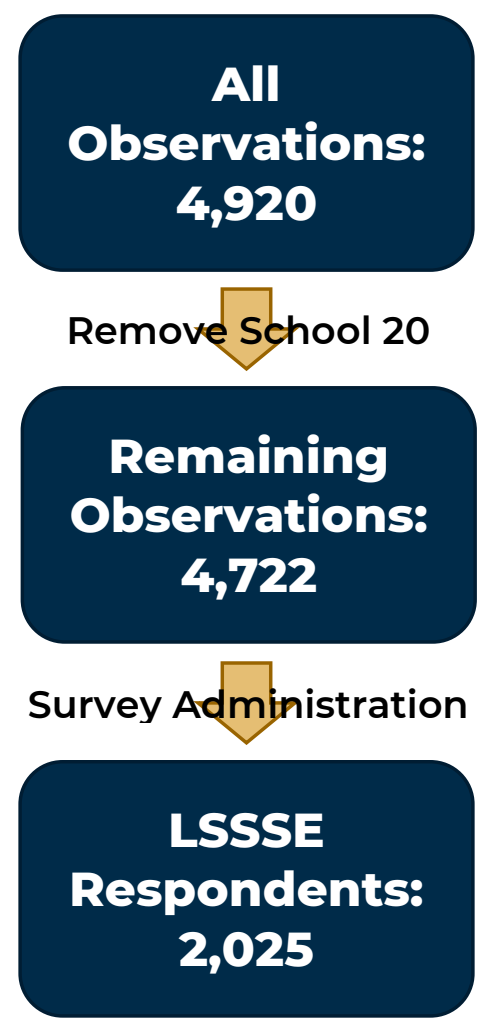

Responses were matched to each graduate's pre-admission and law school transcript data. After matching, all information identifying students and law schools was deleted and replaced with assigned numbers. For students, the number was randomly generated and assigned. For schools, a School ID, spanning the numbers one to twenty-one, was assigned. Analyses were conducted using this de-identified dataset. Neither students nor schools will be identified by name in this report. Schools will be referred to by their School ID.

In examining the differences between the three schools with one year of survey data and those with two, and restricting the comparison to those observations with survey data, the three schools collectively do not appear to differ systematically in measures of our outcomes of interest nor racial composition. (See the Online Appendix for a more thorough discussion.)

Overall, the schools in our sample represent a diverse cross-section of the broader population of 198 ABA-approved law schools. The full sample and the subsample of LSSSE respondents appear to be reasonably representative of the national population of law students, particularly in terms of median LSAT, median UGPA, and bar passage rates (Table 1). We consider these factors to be important when speculating about the degree of generalizability of the findings.

The racial and ethnic composition of our samples do differ to notable degrees from the national population of law students. White and Asian graduates are overrepresented in both samples to statistically significant extents compared to the national population. Hispanic graduates are underrepresented in both samples to statistically significant extents. Black graduates are underrepresented in both samples, but the difference within the full sample is not statistically significant (Table 1). In our analyses, we include race/ethnicity as a control variable to account for lurking, unobserved impacts.

Regarding gender, there is a statistically significant difference in composition between the full sample and the national population, but this difference is not cause for concern for several reasons. First, the difference is modest, and the statistical significance is more the result of the largeness of the sample sizes 
than of any meaningful imbalance. Second, there do not appear to be any notable relationships between gender and the outcomes that we studied. Men and women in our samples have roughly the same law school grades and bar pass rates. Third, we include gender as a control variable in our analyses to account for confounding factors that might be related to differences in it.

In considering generalizability, the timeframe during which we conducted the study is important. We must consider the extent to which characteristics of the study subjects and their outcomes represent continuations or reasonable variations from previous cohorts and timeframes. In examining trends in bar passage, median LSAT, median UGPA, and demographic enrollment at the study schools from 2011-2019, neither of our study cohorts or their outcomes appear to be exceptional. They are comparable to previous years. Therefore, the study timeframe does not limit the generalizability of the findings.

We do caution against extrapolating our findings to years impacted by the COVID-19 pandemic, including the July 2020 and February 2021 bar exam administrations. The myriad of unprecedented issues and the varied law school and jurisdictional responses renders these years unlike any previous ones. As such, applying the findings from this study to years affected by the COVID-19 pandemic should be done with caution-if not avoided entirely.

TABLE 1

SAMPLE OVERVIEW (INDIVIDUAL-LEVEL)

\begin{tabular}{lccc}
\hline & $\begin{array}{c}\text { Full Sample } \\
(\mathrm{n}=4,722)\end{array}$ & $\begin{array}{c}\text { LSSSE Respondents } \\
(\mathrm{n}=2,025)\end{array}$ & $\begin{array}{c}\text { National } \\
\text { (ABA Law Schools) }\end{array}$ \\
\hline Race (percent) & & & \\
Asian & $8.43^{*}$ & $8.30^{*}$ & 6.39 \\
Black & 7.73 & $6.76^{*}$ & 8.35 \\
Hispanic & $10.61^{*}$ & $8.35^{*}$ & 12.34 \\
White & $63.98^{*}$ & $69.04^{*}$ & 61.44 \\
Two or More & 3.35 & 3.16 & 2.97 \\
Remaining & $3.11^{*}$ & $3.16^{*}$ & 4.12 \\
Unknown & $2.80^{*}$ & $1.23^{*}$ & 4.39 \\
Gender (percent) & & & \\
Female & $54.38^{*}$ & 53.88 & 51.99 \\
Male & $45.62^{*}$ & 46.02 & 47.96 \\
LSAT (median) & 154 & 155 & 154 \\
UGPA (median) & 3.36 & 3.36 & 3.37 \\
First-time bar passage rate & $74.99^{*}$ & 76.64 & 76.86 \\
\hline
\end{tabular}

Source: AccessLex Institute (2020), Admissions [Data set], available from http://analytix.accesslex.org/DataSet; AccessLex Institute (2020), Degrees [Data set], available from http://analytix.accesslex.org/DataSet; AccessLex Institute (2020), Enrollment [Data set], available from http://analytix.accesslex.org/DataSet; AccessLex Institute (2020), 2018 First-Time Exam Takers and Repeaters from ABA-Approved Law Schools (thebarexaminer.org); and 2019 First-Time Exam Takers and Repeaters from ABA-Approved Law Schools (thebarexaminer.org).

Note: *difference is statistically significant $(p<0.05)$ from the national figure; national race/ethnicity figures are based on J.D.'s awarded in 2018 and 2019 (regardless of whether full-time or part-time - this distinction is not made in the ABA Standard 509 Required Disclosure data); national gender data is based on the 3L enrollment for both full- and part-time students (as with race/ethnicity, this distinction is not made in ABA Standard 509 data, it is also not reported with the number of degrees awarded data); national LSAT and UGPA figures represent the median of the medians for each individual ABA law school for the admitted class of 2018; national bar passage rate is the aggregated combined pass rate for the July 2018 and July 2019 bar exam administrations.

In sum, our full sample is reasonably representative of the national population of full-time law students during the study period and in previous years; thus, findings yielded from analyses of the full sample should be generalizable to the broader population of ABA law schools and students. But caution should be exercised in generalizing findings to years impacted by the COVID-19 pandemic. Findings from analyses 
of the LSSSE subsample cannot be generalized with confidence. Although the pool of respondents closely resembles the national population in terms of LSAT, UGPA, and first-time bar passage, there are notable demographic differences that prevent us from generalizing beyond the study schools.

\section{Variables}

Our models use both the academic and LSSSE response data to estimate two outcomes: (1) law school academic performance and (2) first-time bar exam performance.

Law school GPA (LGPA) is our academic performance variable. We analyze five iterations of LGPA: first-semester (1S), first-year (1L), third-year (3L), final, and LGPA growth - the difference between final and $1 \mathrm{~S} \mathrm{LGPA.}{ }^{3}$ Note that $3 \mathrm{~L}$ LGPA was not provided by schools and is estimated using the provided second-year LGPA and final LGPA, both of which are cumulative measures. Our estimation is imperfect as it does not account for the number of credit hours earned during each period (we do not have this data) and assumes that the credit hours earned during 3L are equal to those earned in earlier years; nonetheless, it is a reasonable approximation of a student's performance in his/her final two semesters.

TABLE 2

\section{STUDENT ENGAGEMENT VARIABLES}

\begin{tabular}{|c|c|}
\hline $\begin{array}{l}\text { Variable Name and Response } \\
\text { Range }\end{array}$ & Variable Description \\
\hline $\begin{array}{l}\text { Learning to Think Like a } \\
\text { Lawyer* }\end{array}$ & $\begin{array}{l}\text { Students think critically, think analytically, and effectively } \\
\text { process information from different contexts and frameworks }\end{array}$ \\
\hline 1 (very little/some)-3 (very much) & (LSSSE, 2013). \\
\hline $\begin{array}{l}\text { Law School Environment* } \\
1 \text { (never/sometimes)-3 (very } \\
\text { often) }\end{array}$ & $\begin{array}{l}\text { Students' perception of the law school in areas such as diversity, } \\
\text { social life, and help coping with non-academic responsibilities, } \\
\text { and how the student perceives their own "fit" in the } \\
\text { environment. (LSSSE, 2013). }\end{array}$ \\
\hline $\begin{array}{l}\text { Student Advising* } \\
1 \text { (unsatisfied)-3 (very satisfied) }\end{array}$ & $\begin{array}{l}\text { The quality and quantity of advisory services such as academic } \\
\text { counseling and career advising offered by law schools (LSSSE, } \\
\text { 2013). }\end{array}$ \\
\hline $\begin{array}{l}\text { Student-Faculty Interaction * } \\
1 \text { (rarely)-3 (often) }\end{array}$ & $\begin{array}{l}\text { How students communicate with faculty (e.g., receiving prompt } \\
\text { feedback or assisting on projects) and what type of advice they } \\
\text { receive (e.g., job search advice) (LSSSE, 2013). }\end{array}$ \\
\hline $\begin{array}{l}\text { Amount of Law School Debt } \\
1(\$ 0-\$ 20 \mathrm{k})-3(\$ 100 \mathrm{k}+)\end{array}$ & $\begin{array}{l}\text { The amount of law school debt respondents expect to have at } \\
\text { graduation. }\end{array}$ \\
\hline $\begin{array}{l}\text { Broad Legal Education } \\
1 \text { (very little/some)-3 (very } \\
\text { much) }\end{array}$ & $\begin{array}{l}\text { The extent to which students perceived that their experience at } \\
\text { law school contributed to acquiring a broad (as opposed to } \\
\text { specialized) legal education. }\end{array}$ \\
\hline $\begin{array}{l}\text { Challenging Coursework } \\
1 \text { (not/a little)-3 (very challenging) }\end{array}$ & $\begin{array}{l}\text { The degree to which students were challenged and put forth } \\
\text { extra effort in their academic lives ("going the extra mile"), } \\
\text { including on exams, homework, and writing assignments. }\end{array}$ \\
\hline $\begin{array}{l}\text { Class Participation } \\
1 \text { (never/sometimes)-3 (very often) }\end{array}$ & $\begin{array}{l}\text { The frequency with which students asked questions in their } \\
\text { courses or contributed to class discussions. }\end{array}$ \\
\hline $\begin{array}{l}\text { Collaboration } \\
0 \text { (never/sometimes)-1 (often/very } \\
\text { often) }\end{array}$ & $\begin{array}{l}\text { The frequency with which students discussed ideas or worked on } \\
\text { assignments with other students, both in and out of the } \\
\text { classroom. }\end{array}$ \\
\hline $\begin{array}{l}\text { Coming to Class Unprepared } \\
1 \text { (often/very often) }-3 \text { (never) }\end{array}$ & $\begin{array}{l}\text { The frequency with which students came to class unprepared } \\
\text { (e.g., did not do the reading assignment). }\end{array}$ \\
\hline
\end{tabular}




\begin{tabular}{|c|c|}
\hline $\begin{array}{l}\text { Diverse Knowledge Displayed } \\
1 \text { (never/sometimes)-3 (very } \\
\text { often) }\end{array}$ & $\begin{array}{l}\text { The frequency with which class discussions and writing } \\
\text { assignments included perspectives (e.g., ethnic or religious } \\
\text { background) and conceptual ideas from other courses perspectives } \\
\text { in class discussions and writing assignments. }\end{array}$ \\
\hline $\begin{array}{l}\text { Emphasis on Academics } \\
1 \text { (very little/some)-3 (very } \\
\text { much) }\end{array}$ & $\begin{array}{l}\text { The extent to which a law school encourages students to take } \\
\text { part in an academically holistic law school experience. }\end{array}$ \\
\hline $\begin{array}{l}\text { Extracurricular Legal Experience } \\
1(0 \mathrm{hr} .)-4(21+\mathrm{hr} .)\end{array}$ & $\begin{array}{l}\text { The amount of time per week students spent working in the legal } \\
\text { field, either through pro bono work or in a paid, law-related job. }\end{array}$ \\
\hline $\begin{array}{l}\text { Other Responsibilities } \\
1(0-5 \mathrm{hr} .)-3(21+\mathrm{hr} .)\end{array}$ & $\begin{array}{l}\text { The amount of time per week students spent on activities not } \\
\text { directly related to their education. }\end{array}$ \\
\hline $\begin{array}{l}\text { Practical Skills } \\
1 \text { (very little/some)-3 (very much) }\end{array}$ & $\begin{array}{l}\text { The extent to which students perceived their law school experience } \\
\text { contributed to developing tangible skills that are important for } \\
\text { success as an attorney, such as effective speaking, research, and } \\
\text { writing. }\end{array}$ \\
\hline $\begin{array}{l}\text { Preparation for Class } \\
1(0-20 \mathrm{hr} .)-3(31+\mathrm{hr} .)\end{array}$ & $\begin{array}{l}\text { The amount of time per week students reported spending } \\
\text { preparing for class, on average. }\end{array}$ \\
\hline $\begin{array}{l}\text { School Satisfaction } \\
1 \text { (unsatisfied)-3 (very satisfied) }\end{array}$ & $\begin{array}{l}\text { The level of satisfaction that students reported with their } \\
\text { education experience, and whether they would choose the same } \\
\text { law school if they started over. }\end{array}$ \\
\hline $\begin{array}{l}\text { Self-Care } \\
1(0-10 \mathrm{hr} .)-3(26+\mathrm{hr} .)\end{array}$ & $\begin{array}{l}\text { The amount of time per week students participate in non- } \\
\text { academic activities, such as exercising or participating in } \\
\text { community organizations. }\end{array}$ \\
\hline $\begin{array}{l}\text { Supportive Relationships } \\
1 \text { (modestly helpful)-4 (helpful) }\end{array}$ & $\begin{array}{l}\text { The degree to which students felt their relationships with } \\
\text { faculty, administrative staff, and other students were helpful and } \\
\text { provided a sense of belonging. }\end{array}$ \\
\hline
\end{tabular}

Each LGPA variable (excluding growth) is standardized within each school such that the mean of each school is assigned a value of zero and all other values for a given school are assigned above or below zero based on their distance from the mean and relative to the standard deviation. This allows us to account for variation in grading policies between schools and for changes in grading practices and trends as students progress through law school (e.g., grade inflation in later years). LGPA growth is calculated as the difference between the standardized Final LGPA and standardized 1S LGPA values.

The focus of our analyses is to estimate the extent to which certain variables have a statistical relationship with LGPA. We use LSAT score and UGPA as explanatory variables in our analyses of all five iterations of LGPA. For 3L LGPA, we add 19 student engagement variables. Four of these variables are composites of multiple LSSSE Survey questions, called Engagement Indicators. The remaining 15 are specific survey questions or composites of questions that we identified as potentially having the greatest impact (Table 2). When combining LSSSE Survey items to create thematic composite variables, we used confirmatory factor analysis to verify that our composite variables explained a common, unobserved dimension and should therefore be considered valid. (See the Online Appendix for more detail about the variable selection process.)

First-time bar result (pass/fail) is our bar exam passage variable. For each graduate cohort, we analyze results from either the July 2018 or July 2019 exam, whichever is the first administration following its graduation. Focusing on the most immediate bar exam after graduation helps minimize the influence of unobserved or confounding factors on our analyses. The more time that elapses, the less precise and, potentially, less valid our findings become. Additionally, first-time bar result is probably the most highly scrutinized law school outcome, maximizing the practical value of our study focus.

The focus of our analyses is to estimate the extent to which certain variables have a correlational or predictive relationship to bar exam result. 


\section{Models}

Each model employs either linear or logistic fixed effects (non-pooling) regression. Table 3 describes, by research question, our explanatory and outcome variables, the regression method employed, and the number of observations.

Linear regression is generally used when the outcome variable is continuous and normally distributed, although this is not a requirement (see, for example, Agresti and Finlay, 1986; and King et al., 1994). One of the advantages to this method is that it produces a coefficient that is directly interpretable. The coefficient reflects the impact of a one-unit change in the explanatory variable on the outcome variable, while holding all other variables constant. For example, linear regression allows us to measure the impact of a one-point increase in LSAT score on 1S LGPA. This is a powerful means of interpreting relationships between variables.

Logistic regression is used when the outcome variable is binary (e.g., bar exam pass/fail). Unlike the outputs from linear regression, the results from logit regressions are not directly interpretable. Logistic regression modeling produces outputs called "log odds," which provide insight on the relationship between variables that we analyze. Log odds tell us two things: 1) general information about the impact of a change in the explanatory variable (or set of variables) on the outcome variable; and 2) whether those impacts are statistically significant. But log odds do not directly communicate, for example, the impact of a one-point increase in LSAT score on the likelihood of bar passage.

In order to increase the usefulness of the logistic regression outputs, we do two things. First, we transform the log odds into odds ratios, which help frame the strength of the relationship between the variables. Based on odds ratios, we can frame the size of relationships as small, medium, or large.

Second, we calculate the predicted probability of bar passage based on the average amount of change of a given explanatory variable. Predicted probabilities are particularly useful because they help localize the impact of factors of interest by controlling for other potentially relevant factors.

TABLE 3

MODELS AND VARIABLES EMPLOYED BY RESEARCH QUESTION

\begin{tabular}{|c|c|c|c|c|c|}
\hline & Model & Obs. & $\begin{array}{l}\text { Method } \\
\text { (Linear or }^{\text {Logistic) }}{ }^{1} \\
\end{array}$ & $\begin{array}{l}\text { Explanatory } \\
\text { Variable(s) }\end{array}$ & $\begin{array}{l}\text { Outcome } \\
\text { Variable }\end{array}$ \\
\hline \multirow{5}{*}{$\begin{array}{l}\text { Question 1: } \\
\text { To what } \\
\text { extent do } \\
\text { LSAT score } \\
\text { and UGPA } \\
\text { predict law } \\
\text { school } \\
\text { academic } \\
\text { success and } \\
\text { first-time bar } \\
\text { passage? }\end{array}$} & $\begin{array}{l}\text { Bar Result given } \\
\text { incoming } \\
\text { indicators }\end{array}$ & 4,113 & Logistic & LSAT and UGPA & Bar result \\
\hline & $\begin{array}{l}\text { 1S LGPA given } \\
\text { incoming } \\
\text { indicators }\end{array}$ & 3,938 & Linear & LSAT and UGPA & 1S LGPA \\
\hline & $\begin{array}{l}\text { 1L LGPA given } \\
\text { incoming } \\
\text { indicators }\end{array}$ & 3,941 & Linear & LSAT and UGPA & 1L LGPA \\
\hline & $\begin{array}{l}\text { Final LGPA given } \\
\text { incoming } \\
\text { indicators }\end{array}$ & 4,223 & Linear & LSAT and UGPA & Final LGPA \\
\hline & $\begin{array}{l}\text { LGPA growth } \\
\text { given incoming } \\
\text { indicators }\end{array}$ & 3,938 & Linear & LSAT and UGPA & LGPA growth \\
\hline
\end{tabular}




\begin{tabular}{|c|c|c|c|c|c|}
\hline \multirow{4}{*}{$\begin{array}{l}\text { Question 2: } \\
\text { To what } \\
\text { extent does } \\
\text { law school } \\
\text { academic } \\
\text { performance } \\
\text { predict bar } \\
\text { passage? }\end{array}$} & $\begin{array}{l}\text { Bar result given } 1 \mathrm{~S} \\
\text { LGPA }\end{array}$ & 3,846 & Logistic & 1S LGPA & Bar result \\
\hline & $\begin{array}{l}\text { Bar result given 1L } \\
\text { LGPA }\end{array}$ & 3,850 & Logistic & 1L LGPA & Bar result \\
\hline & $\begin{array}{l}\text { Bar result given } \\
\text { final LGPA }\end{array}$ & 4,113 & Logistic & Final LGPA & Bar result \\
\hline & $\begin{array}{l}\text { Bar result given } \\
\text { LGPA growth }\end{array}$ & 3,846 & Logistic & LGPA Growth & Bar result \\
\hline \multirow{3}{*}{$\begin{array}{l}\text { Question 3: } \\
\text { What student } \\
\text { engagement } \\
\text { factors are } \\
\text { associated } \\
\text { with bar } \\
\text { passage? }\end{array}$} & $\begin{array}{l}\text { Bar result given } \\
\text { LSSSE } \\
\text { Engagement } \\
\text { Indicators }^{2}\end{array}$ & 1,451 & Logistic & LSSSE EIs & Bar result \\
\hline & $\begin{array}{l}\text { Bar result given } \\
\text { School-Related } \\
\text { Factors }^{3}\end{array}$ & 1,408 & Logistic & $\begin{array}{l}\text { School-Related } \\
\text { Engagement } \\
\text { Factors } \\
\end{array}$ & Bar result \\
\hline & $\begin{array}{l}\text { Bar result given } \\
\text { Student-Centered } \\
\text { Factors }^{3}\end{array}$ & 1,366 & Logistic & $\begin{array}{l}\text { Student-Centered } \\
\text { Engagement } \\
\text { Factors }\end{array}$ & Bar Result \\
\hline \multirow{3}{*}{$\begin{array}{l}\text { Question 4: } \\
\text { What student } \\
\text { engagement } \\
\text { factors are } \\
\text { associated } \\
\text { with law } \\
\text { school } \\
\text { academic } \\
\text { performance? }\end{array}$} & $\begin{array}{l}\text { 3L LGPA given } \\
\text { LSSSE EIs }^{2}\end{array}$ & 1,461 & Linear & LSSSE EIs & 3L LGPA \\
\hline & $\begin{array}{l}\text { 3L LGPA given } \\
\text { School-Related } \\
\text { Factors }^{3} \\
\end{array}$ & 1,459 & Linear & $\begin{array}{l}\text { School-Related } \\
\text { Engagement } \\
\text { Factors } \\
\end{array}$ & 3L LGPA \\
\hline & $\begin{array}{l}\text { 3L LGPA given } \\
\text { Student-Centered } \\
\text { Factors }^{3}\end{array}$ & 1,413 & Linear & $\begin{array}{l}\text { Student-Centered } \\
\text { Engagement } \\
\text { Factors }\end{array}$ & 3L LGPA \\
\hline \multicolumn{6}{|c|}{$\begin{array}{l}\text { Note: }{ }^{1} \text { All models in this study use fixed effects estimation to account for nesting within the data; }{ }^{2 \text { "EI" refers to }} \\
\text { "engagement indicator," the term for the four composite variables that LSSSE itself creates and includes in its own } \\
\text { reporting; }{ }^{3} \text { For model parsimony, we divide the remaining collection of } 15 \text { student engagement factors into } 2 \\
\text { separate models: school-related (e.g., school support for non-academics) and student-centered (e.g., legal work } \\
\text { performed) explanatory variables (adding all variables into one single model would lead to model overfitting, } \\
\text { particularly in the case of the fixed effects logistic models). }\end{array}$} \\
\hline
\end{tabular}

\section{Clustering of Observations Within Schools}

In this study, we examine 20 schools, each having its own graduates clustered within it. To account for differences between schools and their impact on graduate outcomes, we employ a hierarchical, fixed effects model which does not allow for the pooling of individuals from different schools. Essentially, we perform two levels of analyses. The first level consists of performing separate regressions for each school, producing 20 sets of school-specific coefficients. The second level consists of calculating an average for each coefficient. This method allows us to condition out any time-invariant law school characteristics that make each institution unique (e.g., size of the law school, setting [urban, rural, suburban], whether a school is a "minority-serving institution")

As shown in Table 4, we utilize a robust set of controls that include, graduation year, race/ethnicity, gender, age, and jurisdiction. Graduation year is a fixed effect that is applied consistently across all models in order to control for variation between the 2018 and 2019 cohorts within each school. To avoid overfitting, the particular control variables employed vary by model based on AIC and BIC values. (The Online Appendix discusses in more detail this process.) 
TABLE 4

CONTROL VARIABLES

\begin{tabular}{|c|c|c|}
\hline Variable Name $^{1}$ & $\begin{array}{l}\text { Variable } \\
\text { Type }\end{array}$ & Description and/or Available Responses \\
\hline Age & Binary & $\begin{array}{l}0 \text {, under 35-years of age; } 1 \text {, at or over 35-years of } \\
\text { age }^{2}\end{array}$ \\
\hline Amount of Law School Debt & Categorical & $\begin{array}{l}\text { The amount of law school debt the student expects } \\
\text { to have upon graduation. } 1(\$ 0)-12 \text { (More than } \\
\$ 200,000)\end{array}$ \\
\hline First-Generation & Binary & $\begin{array}{l}\text { Indicates whether a student comes from a } \\
\text { household where neither parent/guardian obtained } \\
\text { a bachelor's degree: } 1, \text { No; } 2 \text {, Yes }\end{array}$ \\
\hline First-Semester LGPA ${ }^{3}$ & Continuous & $\begin{array}{l}\text { Accounts for starting LGPA, given that those with } \\
\text { higher first-semester LGPAs have greater statistical } \\
\text { likelihood of either diminishment or marginal } \\
\text { improvement in LGPA (and vice versa). }\end{array}$ \\
\hline Gender & Categorical & Either "Female" or "Male". \\
\hline Graduation Year & Categorical & Indicates graduation cohort: “2018” or "2019”. \\
\hline Jurisdiction $^{4}$ & Binary & $\begin{array}{l}\text { Differentiates those taking the bar in California, } \\
\text { which is widely recognized as one of the most } \\
\text { difficult exams. }\end{array}$ \\
\hline Missing Semester 1 LGPA & Binary & $\begin{array}{l}\text { Indicates whether an observation is missing a value } \\
\text { for Semester } 1 \text { LGPA, which serves as a proxy for } \\
\text { a student's transfer status (either from another } \\
\text { school or from part-time to full-time status). }\end{array}$ \\
\hline Race & Categorical & $\begin{array}{l}\text { Either "White," "Asian," "Black," "Hispanic," } \\
\text { "Two or More," or "Remaining"" }\end{array}$ \\
\hline
\end{tabular}

Note: ${ }^{1}$ Not all control variables are employed in all models, see the regression outputs in the appendix for the list of control variables included in each model; ${ }^{2}$ This cutoff was selected due to noticeable differences in non-academic responsibilities between those younger and older than $35 ;{ }^{3}$ For models using LGPA growth only; ${ }^{4}$ For models with bar passage as the dependent variable only.

\section{RESULTS}

We take a multi-faceted approach to interpreting results, particularly those related to the engagement factors that we study. Chiefly, we consider the interplay between practical significance and statistical significance. Throughout, we highlight results that are large or small enough to have practical significance (i.e., for odds ratios, those greater than 1.5 or less than $0.75^{4}$ ), regardless of whether they are statistically significant (though we do provide confidence intervals and indicate significance for each). In general, we place greater emphasis on findings that are both practically and statistically significant.

\section{LSAT Score and UGPA as Predictors of Academic Performance and Bar Passage}

LSAT score and UGPA bear considerable weight in the admission process. Therefore, we examine the strength of relationships between these factors and the main outcomes of interest: LGPA and first-time bar exam performance. We also track how those relationships change over the course of matriculation, from first semester to graduation.

When interpreting these results, it should be noted that there is some level of "weeding out" that occurs in the admission process and during law school (e.g., student attrition). Our sample comprises only individuals who gained admission, enrolled, and remained enrolled through graduation. Unfortunately, our 
analyses do not and cannot speak to relationships among applicants who never enrolled or students who did enroll, but left school (via either attrition or transfer) prior to graduation.

\section{LSAT and UGPAA Are Positively Associated With LGPA}

We find positive, statistically significant relationships between LGPA and both LSAT score and UGPA (Figure 3). At its strongest, a one standard deviation (roughly 6 points) increase in LSAT score is associated with a 0.38 standard deviation increase in 1L LGPA. The exact interpretation will vary by school, but this is approximately equal to a 0.16 grade point increase in 1L LGPA across our standardized sample of 20 schools. The coefficient is similar for UGPA: a one standard deviation (roughly 0.44 grade points) increase in UGPA is associated with a 0.27 standard deviation increase in 1L LGPA, or approximately 0.12 grade points. Notably, neither LSAT score nor UGPA are meaningfully related to LGPA growth.

\section{FIGURE 2 \\ EFFECTS OF LSAT AND UGPA ON LAW SCHOOL GPA}

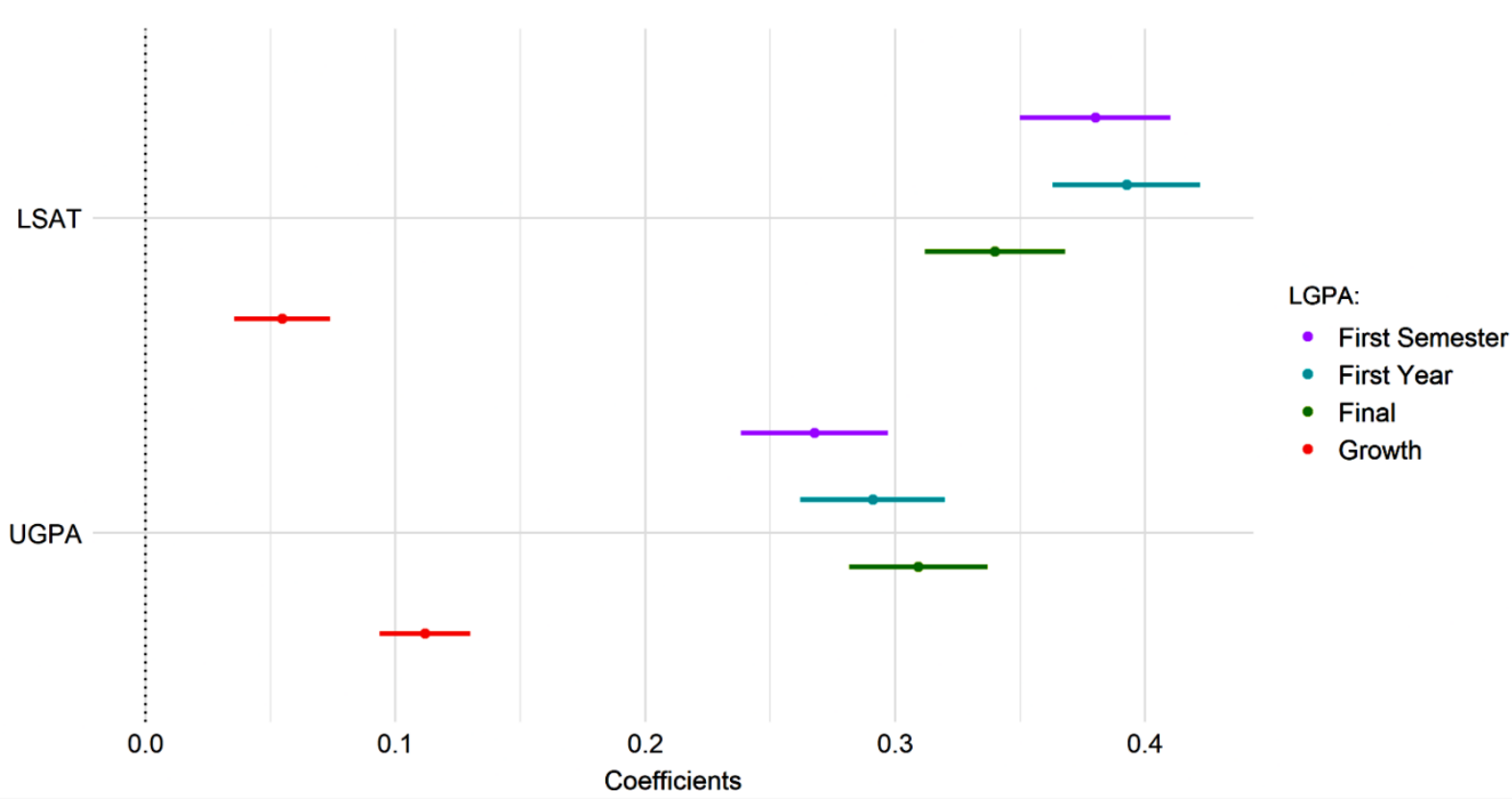

These coefficients suggest that while LSAT and UGPA may have tangible value as explanatory variables of law school academic performance, that value is modest. But it is possible that our analyses understate the impact of these variables. As we noted earlier, we were able to analyze only the outcomes of individuals who gained admission, enrolled, and graduated from the study schools. We were unable to account for the pre-admission sifting of applicants or for law school attrition or transfer. These limitations aside, the smallness of the coefficients suggest that even with the possibility of understatement, the impact of these variables on outcomes is likely limited.

\section{LSAT and UGPA Are Positively Associated With Bar Exam Performance}

As with our LGPA analyses, we find positive and statistically significant relationships between bar exam performance and both LSAT score and UGPA. The analyses yield odds ratios of 1.71 for LSAT score and 1.44 for UGPA. ${ }^{5}$ These ratios mean that a one standard deviation increase in either LSAT score or UGPA is associated with a percent increases in odds of passing the bar of 71 and 44 percent, respectively. 
FIGURE 3

\section{CHANGE IN EFFECT SIZE OF LSAT AND UGPA ON BAR PASSAGE AS LGPA VARIABLES} ARE ADDED ODDS RATIOS AND 95 PERCENT CONFIDENCE INTERVALS

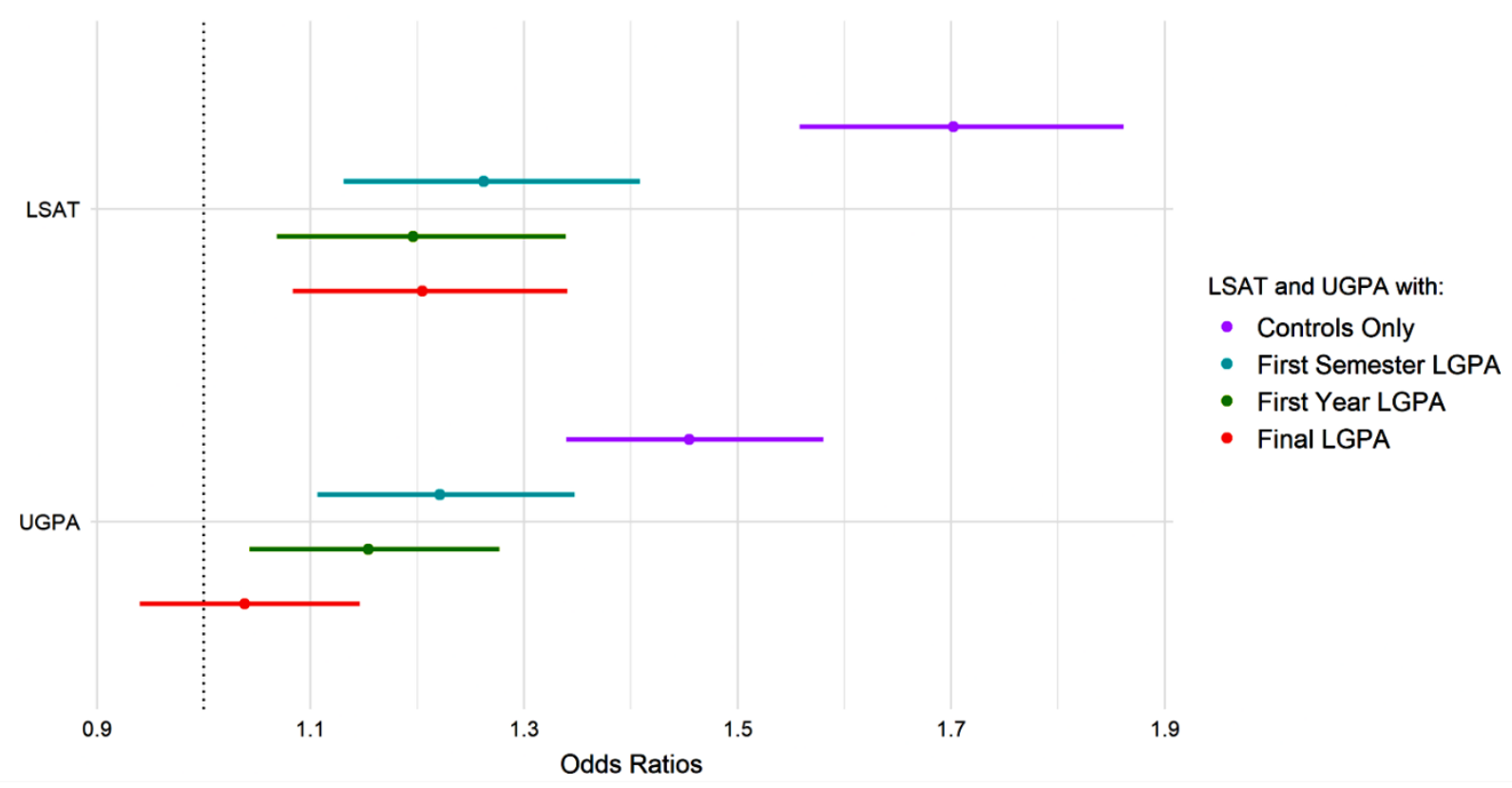

The odds ratios above were yielded using a model that includes LSAT, UGPA, and several control variables (i.e., gender, race, age, graduation year, and whether the test was taken in the CA jurisdiction). The strength of the relationships (and the size of the odds ratios) diminish substantially when any of the LGPA variables are added to the model. For example, when 1L LGPA was added, the odds ratios fell to 1.19 for LSAT score and 1.14 for UGPA, values that we do not consider meaningful. ${ }^{6}$ They fall further when Final LGPA is the added variable.

\section{LGPA as a Predictor of Bar Passage}

LGPA Is the Strongest Predictor of Bar Performance

The strongest predictors of bar exam performance are law school grades. We analyzed the impact of law school grades using the four LGPA variables listed earlier, spanning the entire law school experience. The odds ratios range from 3.34 for 1S LGPA to 5.56 for Final LGPA, amounting to large substantive effects. For example, 1L LGPA has an odds ratio of 4.24, meaning that a one standard deviation increase in this variable is associated with a student quadrupling their odds of bar passage. Each LGPA variable has an effect size that is at least twice as large as that of either LSAT or UGPA (Table 5). 
FIGURE 4

\section{EFFECTS OF LSAT SCORE, UGPA, AND LGPA ON BAR PASSAGE ODDS RATIOS AND 95} PERCENT CONFIDENCE INTERVALS

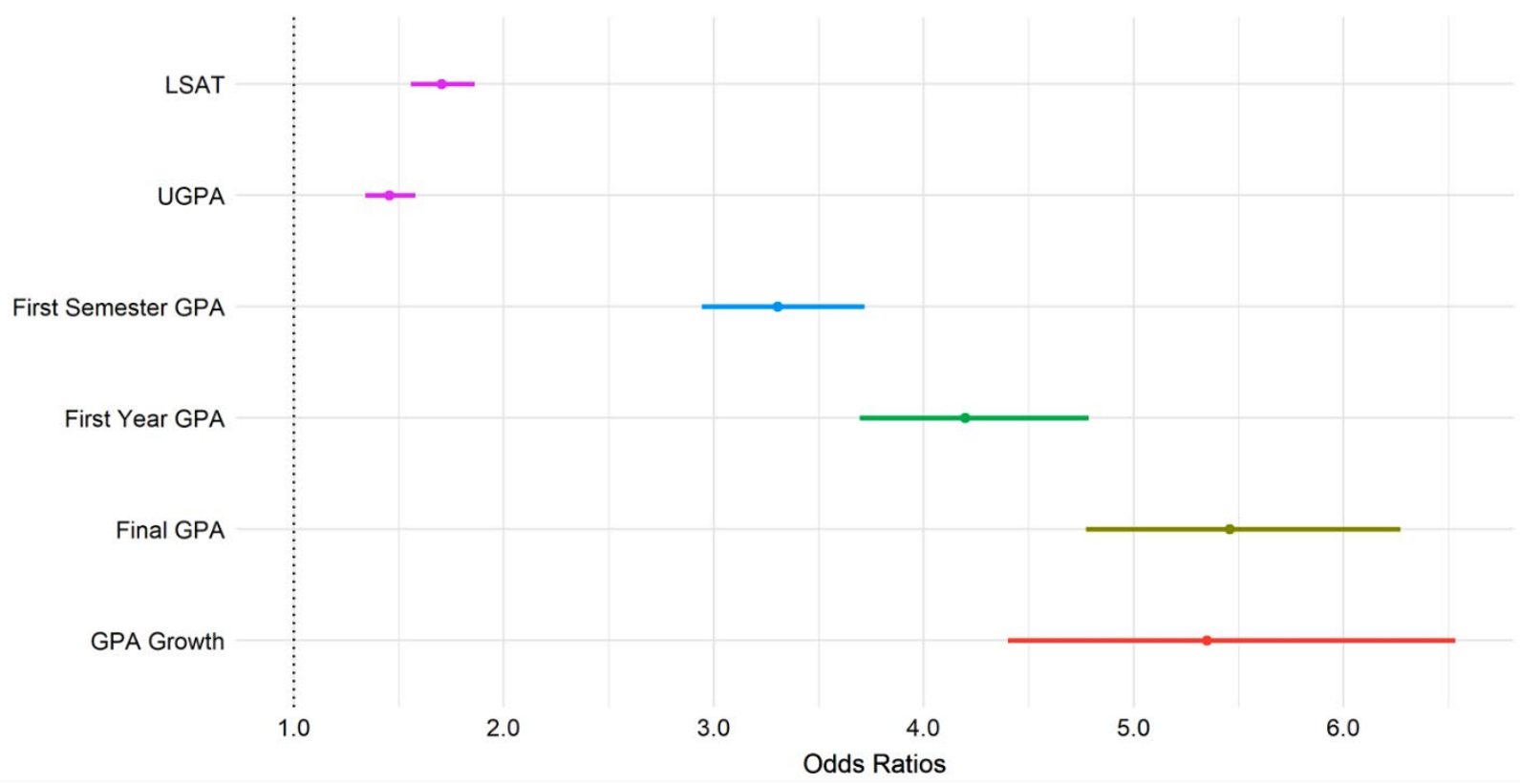

The impact of changes in LGPA over the course of students' law school matriculation is particularly interesting. Recall that the LGPA Growth variable captures the extent to which LGPAs grew or fell between the end of the first semester and graduation. In our analyses, LGPA Growth has an odds ratio of 5.44, meaning that a one standard deviation increase is associated with a student more than quintupling their odds of passing the bar. ${ }^{7}$ This translates to approximately a 15-percentage point increase in the predicted probability of passing the bar for a student with an average 1S LGPA at an average law school (see Figure $5)$.

TABLE 5

(RELATIVE) EFFECT SIZE OF LGPA COMPARED TO LSAT AND UGPA ODDS RATIOS AND EFFECT SIZES RELATIVE TO LGPA

\begin{tabular}{|c|c|c|c|c|c|c|c|c|}
\hline & \multicolumn{2}{|c|}{$\begin{array}{c}\text { First-Semester } \\
\text { LGPA }\end{array}$} & \multicolumn{2}{|c|}{$\begin{array}{l}\text { First-Year } \\
\text { LGPA }\end{array}$} & \multicolumn{2}{|c|}{$\begin{array}{l}\text { Final } \\
\text { LGPA }\end{array}$} & \multicolumn{2}{|c|}{$\begin{array}{c}\text { LGPA } \\
\text { Growth }\end{array}$} \\
\hline & & Relative & & Relative & & Relative & & Relative \\
\hline & OR & OR & OR & OR & OR & OR & OR & OR \\
\hline LGPA & 3.34 & $(1.00)$ & 4.24 & $(1.00)$ & 5.56 & $(1.00)$ & 5.44 & $(1.00)$ \\
\hline LSAT & 1.26 & $(0.38)$ & 1.19 & $(0.27)$ & 1.21 & $(0.22)$ & 1.17 & $(0.22)$ \\
\hline UGPA & 1.20 & $(0.36)$ & 1.14 & $(0.27)$ & 1.02 & $(0.18)$ & 1.02 & $(0.19)$ \\
\hline
\end{tabular}

Note: All ORs reported here are significant at the $p<0.05$ level, except UGPA in the final LGPA and LGPA growth columns. 


\section{FIGURE 5 \\ PREDICTED PROBABILITY OF BAR PASSAGE GIVEN LGPA GROWTH AND FIRST- SEMESTER LGPA}

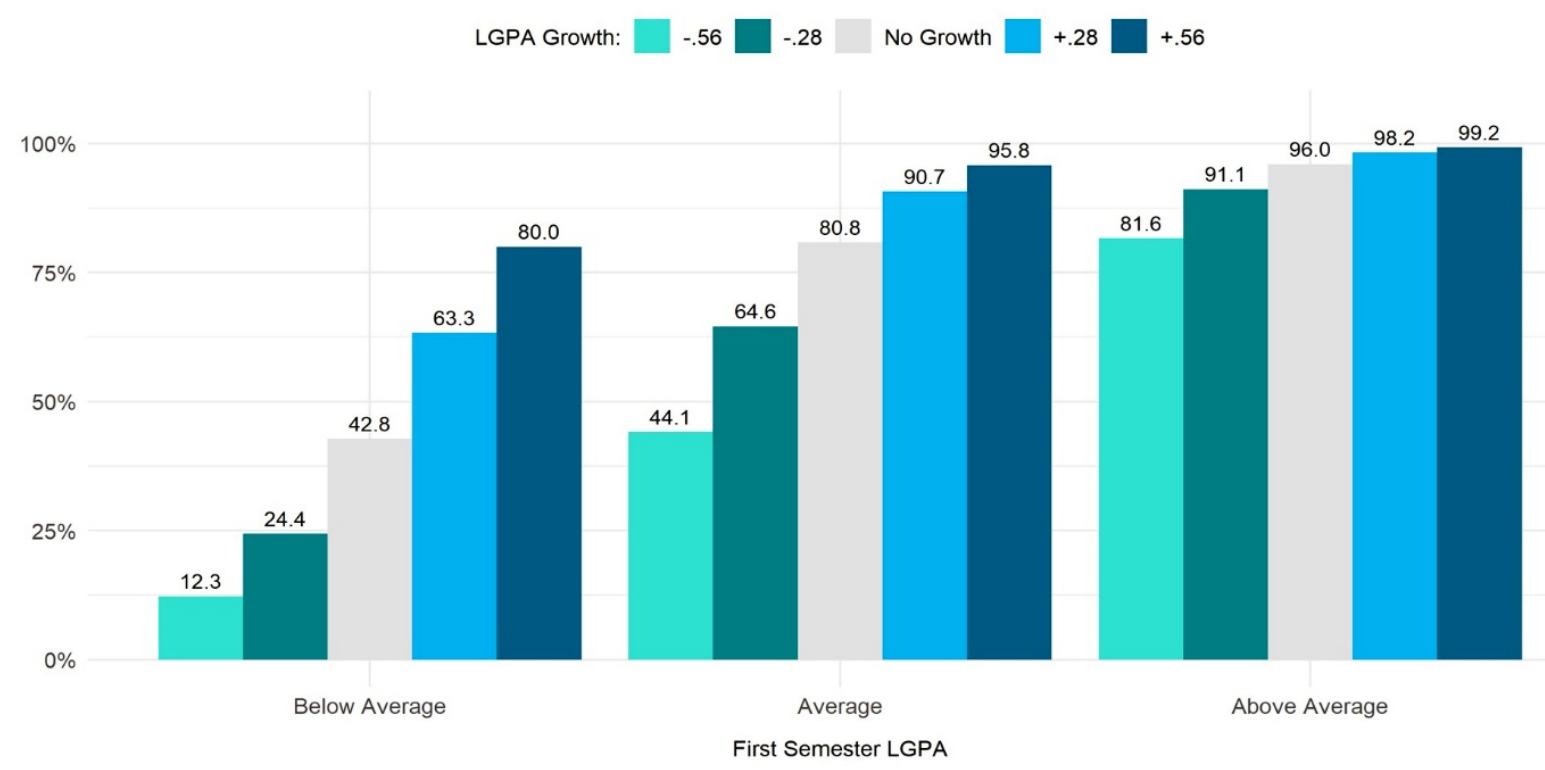

Note: LGPA growth values are the difference between the standardized Final LGPA and the standardized 1S LGPA values.

Figure 5 illustrates the impact of the LGPA Growth variable in nuanced fashion. There are three sets of five bars, each representing a subset of graduates at an average law school (based on percent bar passage) grouped together by where their 1S LGPA fell in the overall distribution at their law school. The group on the left had below average first-semester grades; the middle group had average grades; the group on the right had above average grades. ${ }^{8}$ Each group comprising each five-bar set represents the probability of bar passage based on five LGPA Growth benchmarks: negative growth of 0.56 (one standard deviation) and 0.28 (one-half of a standard deviation); no growth; and positive growth of 0.56 and 0.28 .

The most compelling observation from the figure is the extent to which increases in LGPA impact the bar passage chances of individuals with below average first-semester grades. Graduates with below average first-semester grades who experienced negative LGPA growth had only a 12 or 24 percent chance of passing the bar exam (for negative 0.56 and 0.28 standardized grade point units, respectively) and those with no LGPA growth had a 43 percent chance of passing the bar exam. For those with positive growth, the likelihood of passing increased to 63 and 80 percent for increases of 0.28 and 0.56 standardized grade units, respectively. There were also notable impacts of both positive and negative GPA growth among graduates who had average first-semester grades. The impacts were largely negligible among graduates with above average first-semester grades (except those with the largest decreases in GPA); their chances of passing the bar were already high irrespective of subsequent academic performance.

Both of these latter trends suggest that interventions targeted at students in the bottom two quintiles of the LGPA distribution are likely to have the greatest impact on bar passage than interventions focusing on other students. We expound on this point in the Recommendations section.

\section{Student Engagement as a Predictor of Academic Performance and Bar Passage} Several Modest Effects of Student Engagement on Academic Performance

Our analyses of the student engagement variables were limited to graduates who completed the LSSSE Survey in their final semester of 3L study, making 3L LGPA the most germane academic outcome of interest. As shown in Figure 6, our analyses yield small positive and negative relationships between several 
of the student engagement factors and 3L LGPA. The effect sizes appear quite modest at first blush. For example, the largest effect size is yielded by the Class Participation variable. Participating in class "very often" is associated with a 0.45 standard deviation increase in 3L LGPA compared to the "never/sometimes" response option. In practical terms, this approximates to a difference of about 0.16 grade points.

\section{FIGURE 6 \\ EFFECTS OF STUDENT ENGAGEMENT FACTORS ON 3L LGPA COEFFICIENTS AND 95 PERCENT CONFIDENCE INTERVALS}

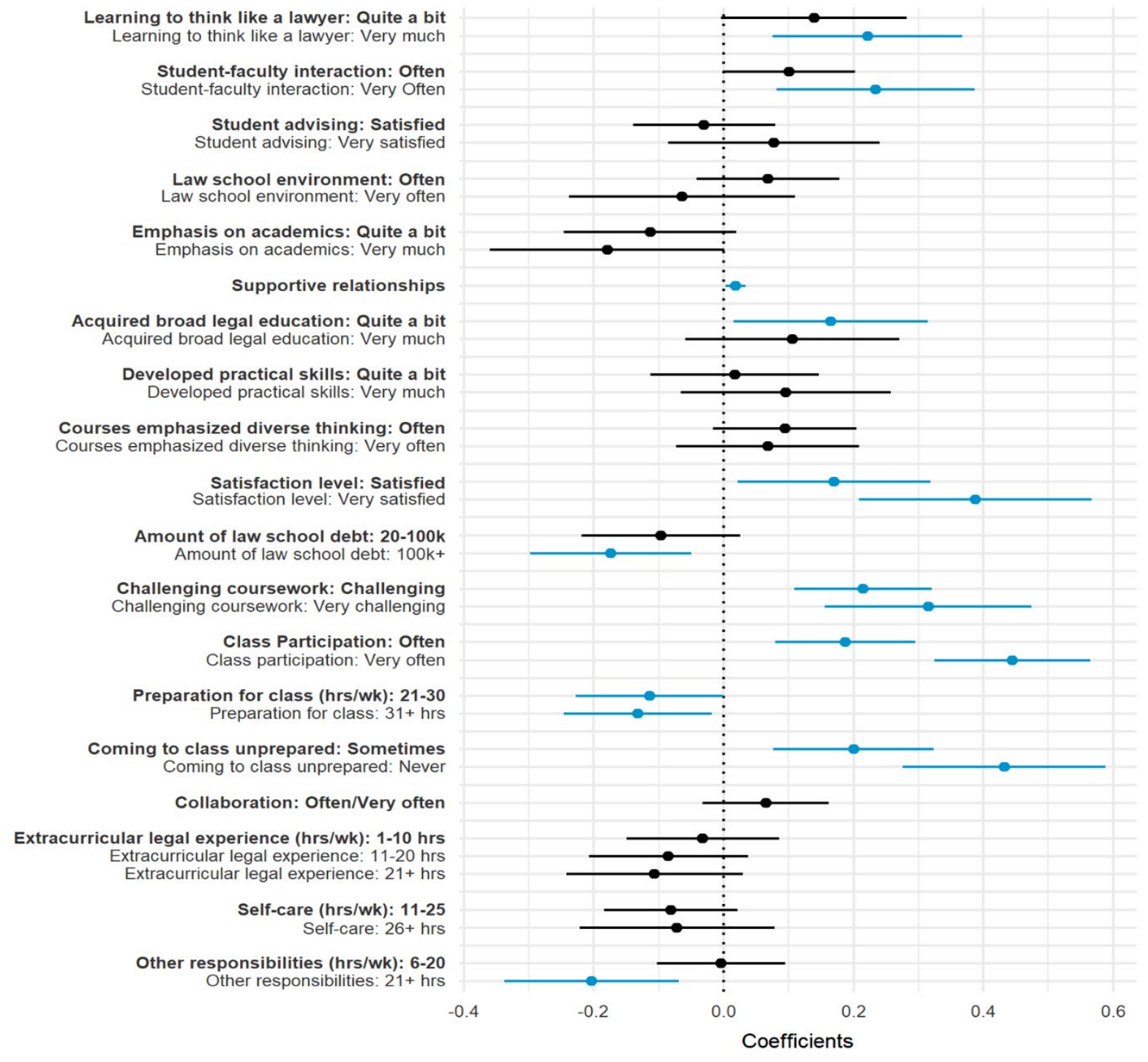

On their own, none of these results are practically significant. However, as we note in our recommendations, student engagement theory emphasizes the importance of fostering learning environments that encourage multifaceted engagement among students. Thus, it might be that these factors should not be considered in isolation, but as complementary. As such, the cumulative impact of several of these small effects could be tangible.

The analyses yield two seemingly contradictory findings that warrant brief mention. On one hand, the Preparation for Class variable is negatively and significantly associated with 3L LGPA; the more hours 
graduates reported spending preparing for class, the lower their 3L LGPA. But the Coming to Class Unprepared variable is positively and significantly associated with 3L LGPA. Graduates who reported "never" coming to class unprepared had higher 3L LGPAs than graduates who reported being unprepared "often" or "very often". The seeming contradiction should not be interpreted to mean that studying does not make a difference; it surely does. The more likely explanation is that graduates who experienced academic difficulty may have simply needed more time to grasp the material or may have been more likely to use inefficient or ineffective study methods that increased their preparation time. Thus, we caution against using a variable measuring the amount of time students report preparing for class when estimating academic outcomes. ${ }^{9}$

Varied Effects of Student Engagement on Bar Passage

Our analyses of the relationships between the LSSSE engagement factors and bar passage reveals a mixture of positive, negative, and null findings (Figure 7).

FIGURE 7

\section{EFFECTS OF STUDENT ENGAGEMENT FACTORS ON BAR PASSAGE COEFFICIENTS AND 95 PERCENT CONFIDENCE INTERVALS}

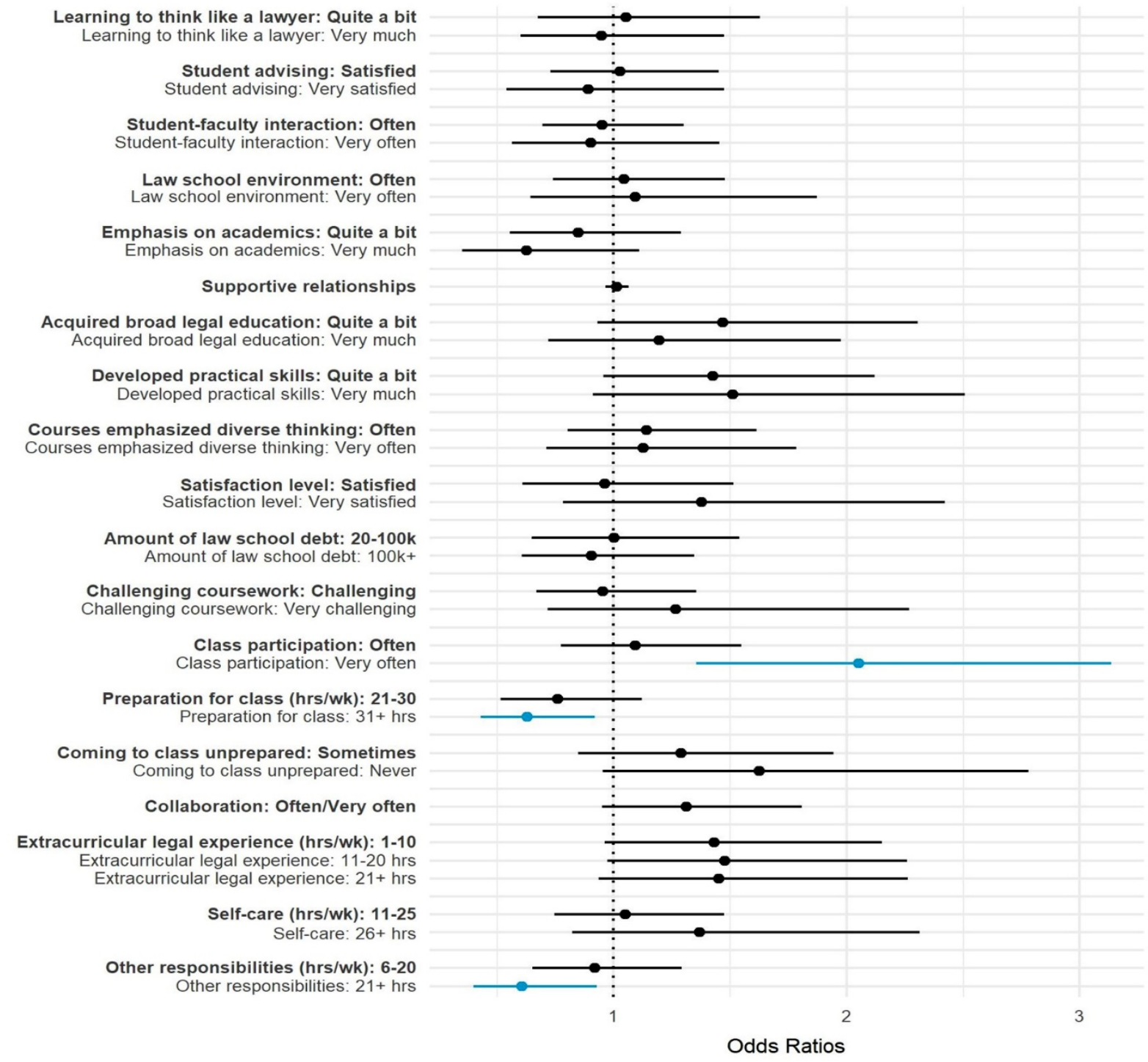

Journal of Higher Education Theory and Practice Vol. 21(10) 2021 


\section{Positive Indicators}

Of the 19 LSSSE factors that we investigate, three have positive and meaningful relationships with bar passage.

Extracurricular Legal Experience. Graduates who reported working in the legal field, either through pro bono work or in a paid, law-related job were more likely to pass the bar exam. The favorable impacts are greatest among graduates who entered law school with below average LSAT scores (Figure 8).

\section{FIGURE 8 \\ PREDICTED PROBABILITY OF BAR PASSAGE GIVEN WEEKLY HOURS OF EXTRACURRICULAR LEGAL EXPERIENCE (BY LSAT SCORE)}

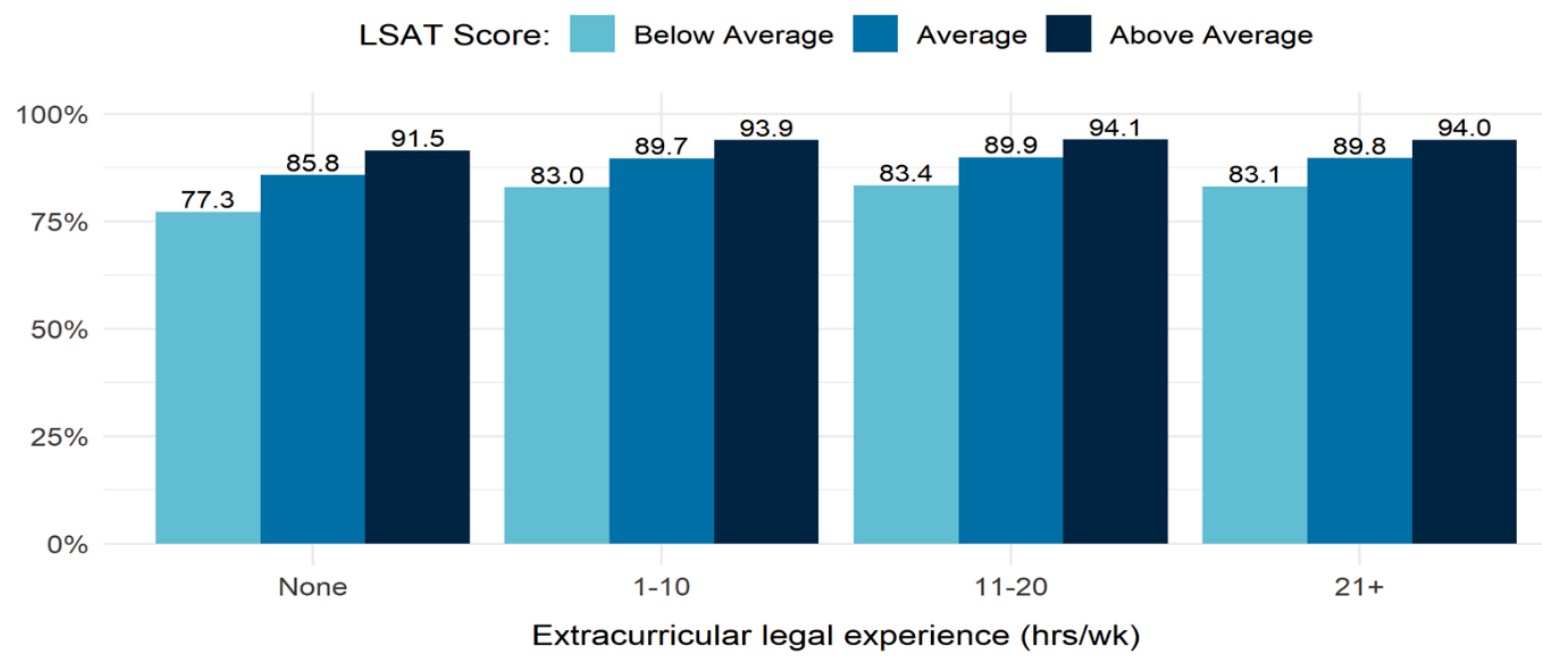

Practical Skills. Graduates who reported that their law school experience contributed "very much" to their development of relevant and tangible skills were more likely to pass the bar exam than other graduates. Once again, the favorable impacts were greatest among graduates who entered law school with below average LSAT scores (Figure 9).

FIGURE 9

PREDICTED PROBABILITY OF BAR PASSAGE GIVEN PRACTICAL SKILLS

(BY LSAT SCORE)

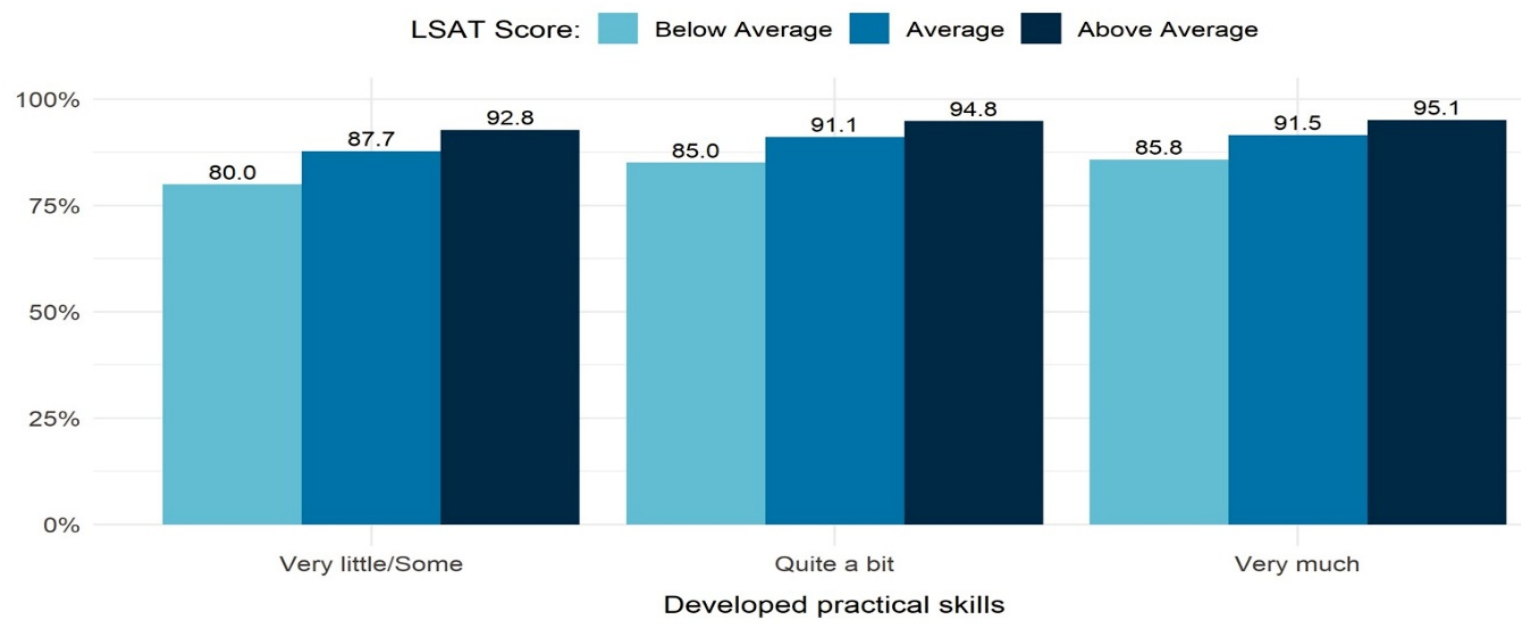

122 Journal of Higher Education Theory and Practice Vol. 21(10) 2021 
Class Participation. Graduates who reported participating in class "very often" were more likely to pass the bar exam than other graduates. Once again, the favorable impacts were greatest among graduates who entered law school with below average LSAT scores (Figure 10).

\section{FIGURE 10 \\ PREDICTED PROBABILITY OF BAR PASSAGE GIVEN CLASS PARTICIPATION (BY LSAT SCORE)}

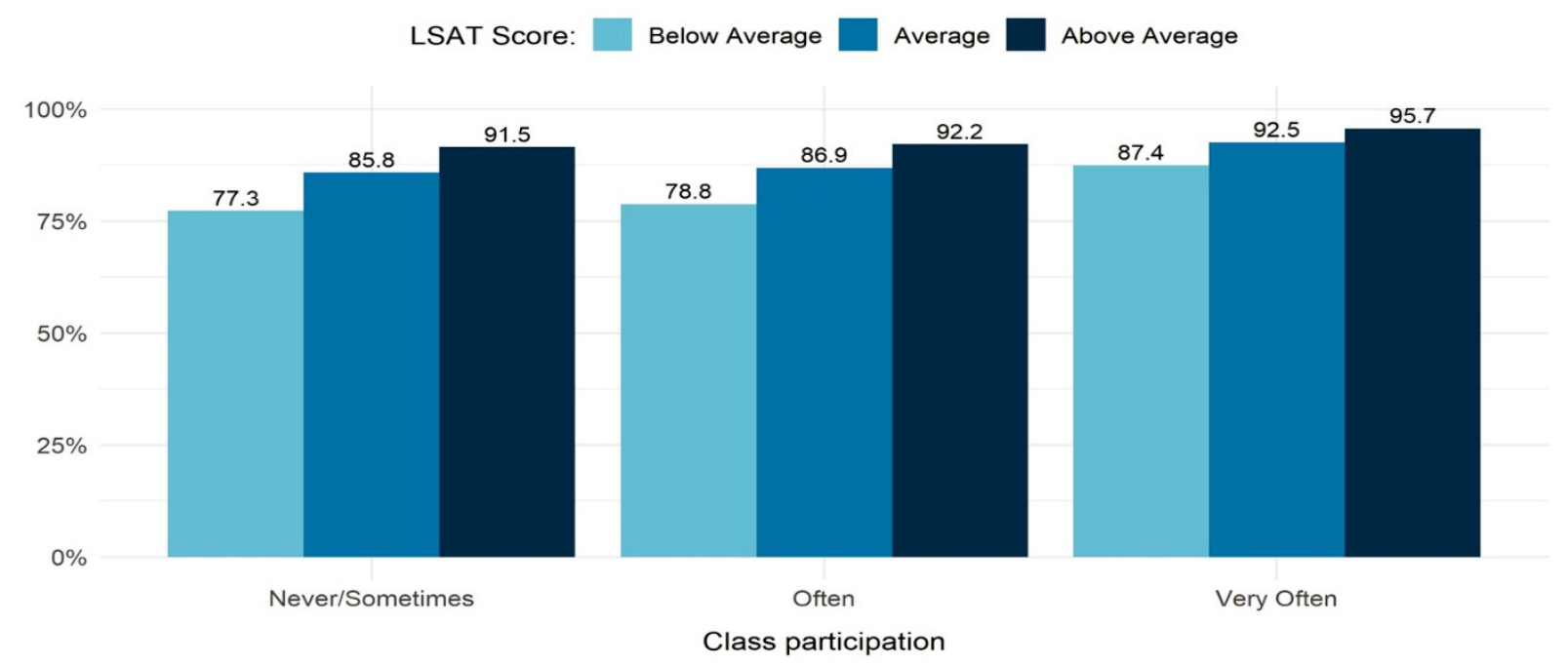

Negative Indicators

One LSSSE factor appears to be convincingly and negatively associated with bar passage.

Other Responsibilities. Graduates who reported spending at least 21 hours per week caring for dependents and/or working a job outside of the legal field were less likely to pass the bar exam than other graduates (Figure 11).

\section{FIGURE 11 \\ PREDICTED PROBABILITY OF BAR PASSAGE GIVEN HOURS PER WEEK OF OTHER RESPONSIBILITIES (BY LSAT SCORE)}

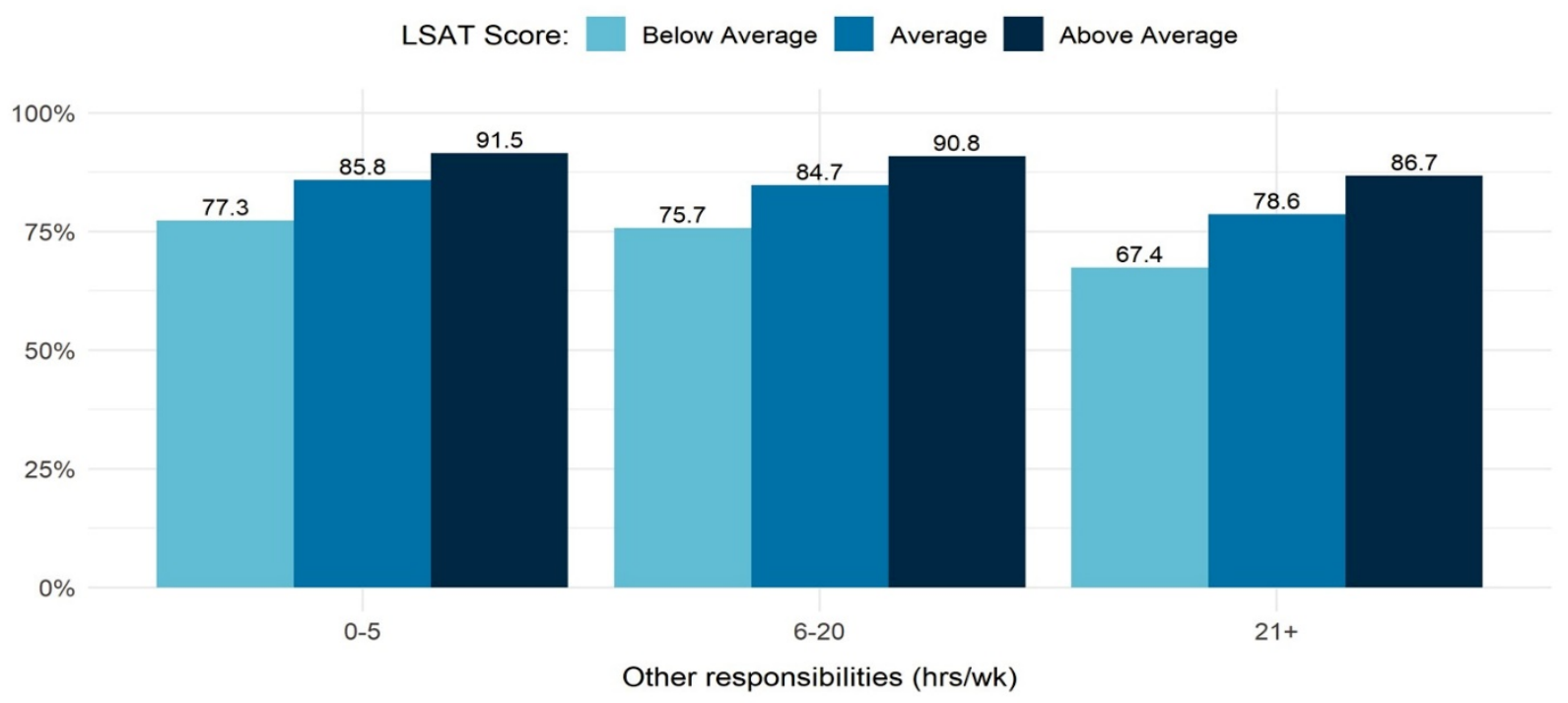




\section{Counterintuitive Findings}

Emphasis on Academics. A decidedly counterintuitive finding is that graduates who reported that their law school encouraged students to take part in an academically holistic law school experience were less likely to pass the bar exam than other graduates. Graduates who responded "very little/some" to the prompt were most likely to pass (Figure 12). This trend held, irrespective of LSAT grouping. We have no reasonable explanation for this finding, particularly in light of findings pertaining to the benefits of gaining relevant practical experience.

\section{FIGURE 12 \\ PREDICTED PROBABILITY OF BAR PASSAGE GIVEN SCHOOL'S EMPHASIS ON ACADEMICS (BY LSAT SCORE)}

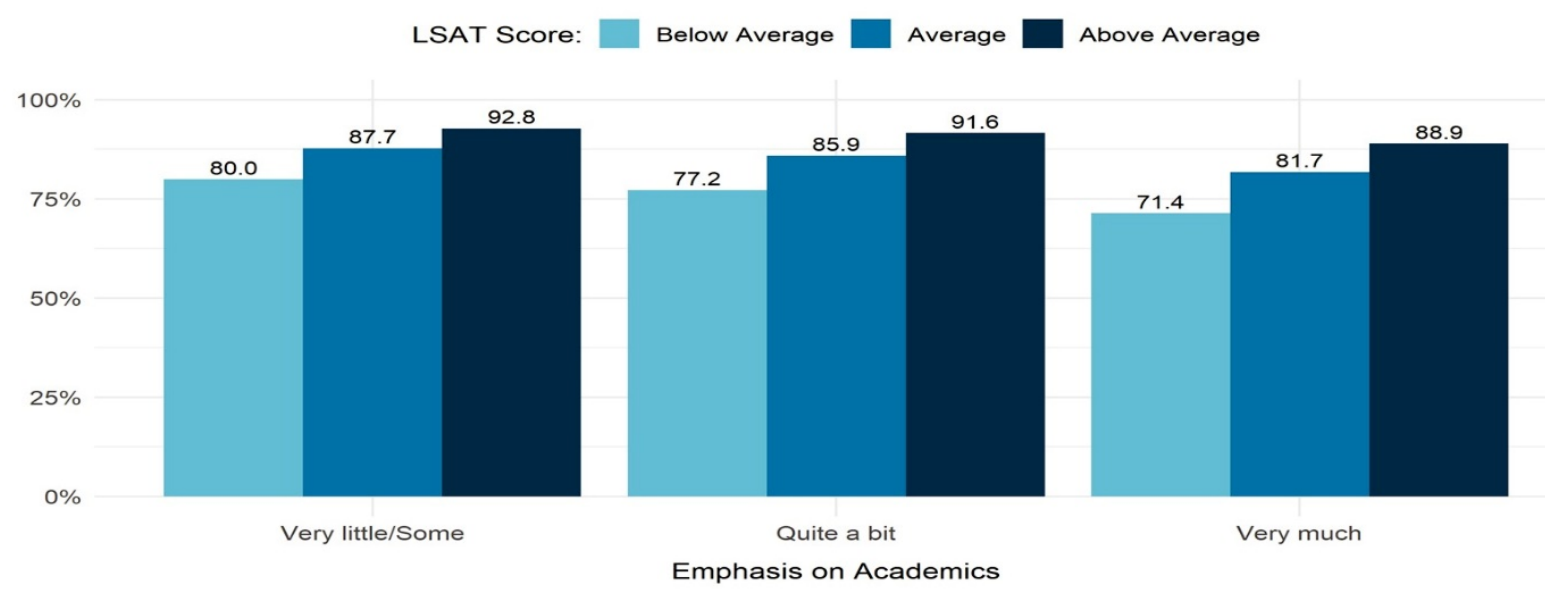

Coming to Class Unprepared and Preparation for Class. Similar to our analysis of student engagement and academic performance, time spent preparing for class was associated with lower chances of passing the bar exam while preparing for class overall was associated with higher chances of passing. These trends held irrespective of LSAT score grouping (Figure 13). As we theorized earlier, this might capture two phenomena pertaining to graduates who were less likely to pass the bar exam: 1) they may have needed more time to grasp the material, or 2) they may have been more likely to use inefficient or ineffective study methods that increased their preparation time.

FIGURE 13

PREDICTED PROBABILITY OF BAR PASSAGE GIVEN PREPARATION FOR CLASS AND COMING TO CLASS UNPREPARED (BY LSAT SCORE)

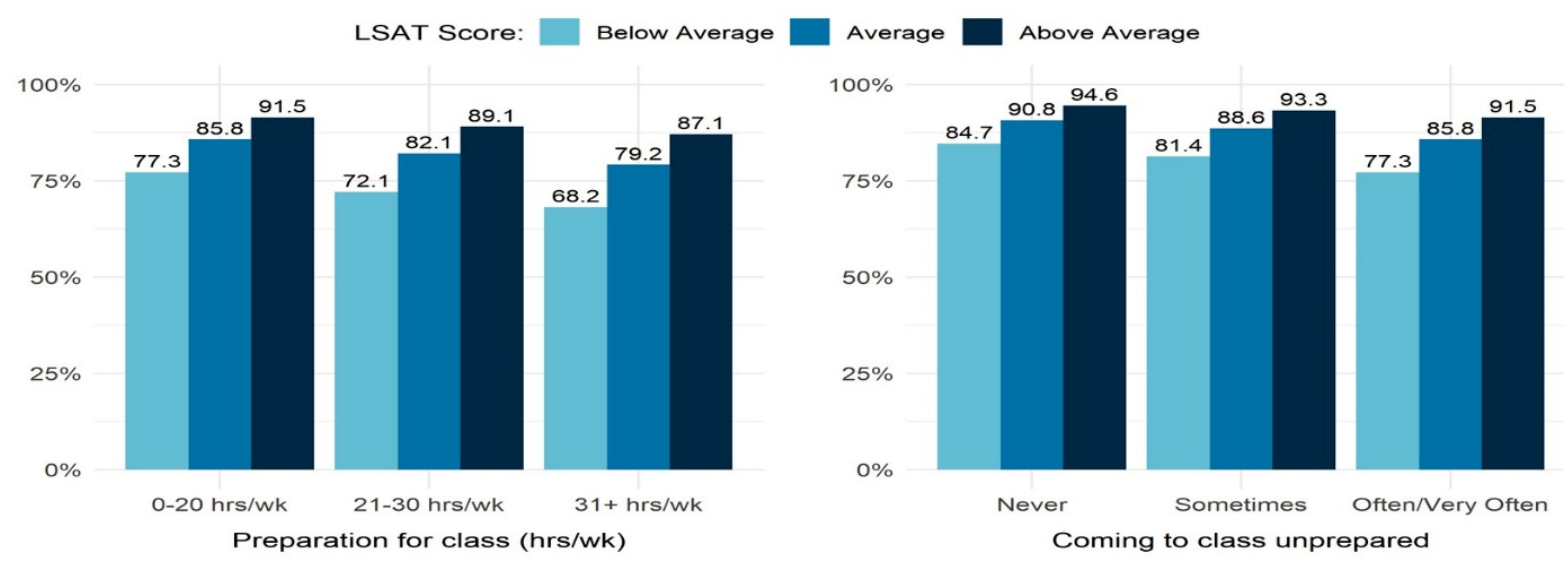

124 Journal of Higher Education Theory and Practice Vol. 21(10) 2021 


\section{Null/Inconclusive Indicators}

We do not find evidence that any of the remaining LSSSE factors, including the LSSSE engagement indicators, are meaningfully related to academic or first-time bar performance. Note that this does not mean that there is definitively no relationship between these variables, only that we fail to find a meaningful substantive impact in this study.

\section{DISCUSSION \& RECOMMENDATIONS}

This study was designed with action in mind. We sought to take an applied approach to our analyses, with the goal of yielding findings that could be used to inform policies, procedures, and practices. To that end, below is a series of action-oriented recommendations rooted in our findings.

\section{Recommendations}

Explore Relevance of Varied Admission Factors

Consistent with extant research, we find that LSAT score and UGPA are modestly predictive of law school academic performance. A one standard deviation (roughly 6 points) increase in LSAT score is associated with a 0.38 standard deviation (approximately 0.16 grade points) increase in 1L LGPA across our standardized sample of 20 schools. A one standard deviation (roughly 0.44 grade points) increase in UGPA is associated with a 0.27 standard deviation increase in 1L LGPA, or approximately 0.12 grade points. (See Figure 2 and Table A.1.) These relationships are considerably weaker for academic performance beyond the first year. Additionally, we find small but notable relationships between LSAT score and UGPA and bar exam passage. A one standard deviation increase in either LSAT score or UGPA is associated with a percent increases in odds of passing the bar of 71 and 44 percent, respectively. More noteworthy, the effects of LSAT and UGPA diminish substantially when LGPA variables are added to the model. (See Figure 3 and Table A.2.)

These findings suggest that while the LSAT score and UGPA have some value as predictors of academic and bar exam performance, their usefulness is limited and they are not determinative of success or failure; therefore, what law schools do after students enroll plays an integral role in their students' success. Law school grades at every stage of matriculation, from the first semester through the last, are by far the strongest predictors of bar exam performance, progressively supplanting pre-admission factors.

The limits of the primary admission factors offer a need and an opportunity for law schools to explore and leverage the predictive value of other aspects of the application. For example, most law schools require applicants to submit personal statements and letters of recommendation. What do these materials tell us about who has the potential to be successful law students and effective and ethical lawyers? Is it possible that these materials have predictive value in their current form? If not, can they be designed in ways that would yield predictive value? If so, these materials could serve as useful components of the admission process, allowing law schools to get a fuller picture of applicant potential in ways that could possibly yield entering cohorts that are more diverse and more likely to experience favorable outcomes.

\section{Encourage Growth Mindset Thinking}

Law school is a distinctive academic experience, and many students find the transition difficult, particularly early on. This difficulty often manifests as less-than-stellar academic performance in the first year, which can lower one's confidence in their ability to do well. These impacts are intensified by the manner in which first-year grades set the tone for future academic and professional opportunities. As discussed earlier, fixed mindset thinking is common among law students and is commonly embedded in policies and practices existing within law schools. But our findings strongly suggest that encouraging growth mindset thinking could not only improve academic performance but increase bar exam pass rates as well.

One of our most robust findings is that improvement in LGPA between the end of the first semester and graduation was associated with increased odds of passing the bar exam, even after controlling for other relevant factors (e.g., entering admission credentials, bar exam jurisdiction) and after accounting for 
differences among schools, including grading policies. (See Figure 4.) The impacts are particularly intense among students who experience the most academic difficulty in the first semester. The average graduate with below average first-semester grades who experienced no LGPA growth had a 43 percent chance of passing the bar exam, compared to 63 percent for a student with positive growth of 0.28 standardized grade points and 24 percent for a student with negative growth of 0.56 standardized grade points. (See Figure 5.)

Schools should nurture growth mindsets among their students by creating learning environments in which policies, practices and messaging emphasize that growth in knowledge, skills and abilities is possible. Students should be encouraged to take ownership of their learning and be provided the instruction and support they need to succeed. Our findings show that doing so can yield substantial benefits.

\section{Intervene Early}

The end of the first year is a common intervention point for law schools seeking to assist students who are experiencing academic difficulty. Less common, although certainly with precedent, are interventions that begin prior to the end of the first year. Our analyses demonstrate that first-semester grades can help both predict bar exam performance and help identify students most at risk of not passing.

Figure 14 shows the predicted probability of passing the bar exam based on LGPA at four points during a student's law school career. In each figure, the slope is steep to the left of the mean (the vertical gray line). Although less pronounced than for 1L LGPA, the slope for 1S LGPA is substantial. An average student at the average school with below average (one standard deviation below the mean) first-semester grades had a 52 percent chance of passing the bar exam, compared to 78 percent for a student with average first-semester grades and 92 percent for a student with above average (one standard deviation above the mean) grades.

\section{FIGURE 14}

\section{PREDICTED PROBABILITY OF BAR PASSAGE GIVEN LGPA PERFORMANCE}
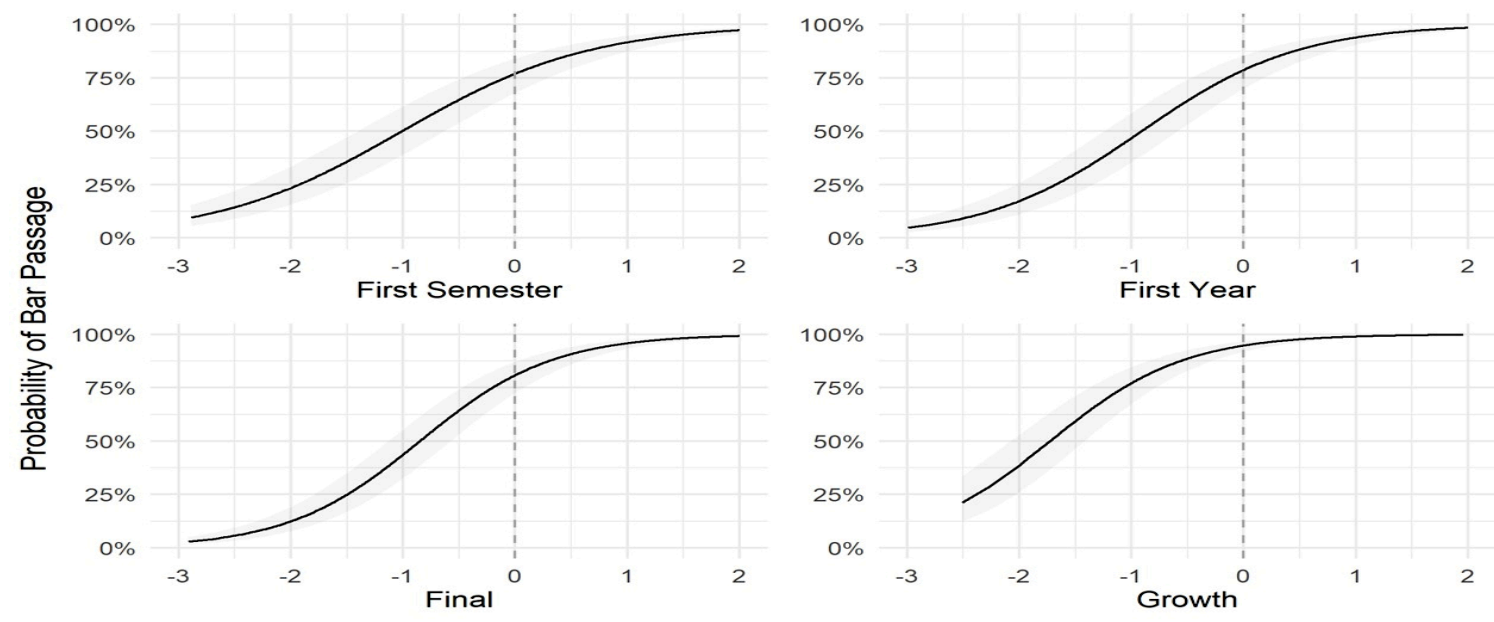

Predicted probabilities are particularly useful because they control for other potentially relevant factors in seeking to localize the impact of the LGPA differences. Our analyses demonstrate the immense usefulness of first-semester grades as an early indicator of bar exam risks. Schools could leverage such data in designing robust interventions that begin six or more months prior to interventions that begin after the end of the first year. The earlier the intervention, the better.

\section{Maximize Opportunities for Student Improvement}

Our data suggest that efforts to increase bar passage rates are most impactfully targeted at students at the lower end of the LGPA distribution (Figure 5). For example, the favorable impact of LGPA growth on 
bar pass odds is most dramatic among students who had below average first-year grades. Enhancing the potential for impact is the fact that these students have statistically the most room and, therefore, opportunity to grow.

Another intriguing finding is that the favorable impacts of higher levels of student engagement were more pronounced among students who entered law school with lower LSAT scores. Things like frequently participating in class (Figure 10) and gaining practical legal experience while in school (Figure 8) increased bar passage odds most noticeably among students with below average LSAT scores, compared to other students.

Our findings highlight the importance of designing curricular and co-curricular frameworks that provide comprehensive support and opportunities for engagement among all students, particularly those who have the most room to improve. These findings may also call into question academic policies that narrow the curriculum for students who experience academic difficulty, increase the number of mandatory courses, and discourage participation in co-curricular activities and relevant employment.

\section{Provide Targeted Support to Students With Outside Responsibilities}

Some students enter law school with significant responsibilities outside of school. For some, these responsibilities can impact their academic performance. Graduates who spent more than 21 hours per week on responsibilities such as caring for dependents or working a non-law-related job had lower 3L LGPAs and bar passage odds than their peers who spent 0 to 5 hours on these activities (Figures 6, 7, and 11). A likely cause of this trend is the simple fact that time and energy spent on other responsibilities can often mean less time spent studying or engaging in schoolwork; this is probably especially true when the other responsibilities are very important, such as caring for a dependent.

The existence of outside responsibilities should not prevent students from thriving. Supporting these students requires law schools to target resources in ways that address needs in relevant ways. These efforts could help promote broad-based student success, given that students with significant outside responsibilities are more likely to come from underrepresented backgrounds or have non-traditional characteristics (e.g., above average age).

\section{Harness the Cumulative Potential of Student Engagement}

There are a number of student engagement factors that each have modest, though tangible, impacts on academic or bar exam performance. Some of these factors appear complementary. For example, favorable responses to the Extracurricular Legal Experience and Class Participation prompts each had modest positive impacts on bar exam passage (Figures 8 and 10, respectively). It seems that in situations where they coexist - a student who is both gaining law-related work experience and actively participating in classesthere is the possibility of a cumulative and magnifying effect. Similarly, Challenging Coursework, Class Participation, Broad Legal Education, and Student-Faculty Interaction each have modest positive effects on 3L LGPA (Figure 6), again suggesting potential for cumulatively favorable impacts.

More research is needed to understand the extent to which these factors complement each other. In the meantime, there is surely no downside to law schools fostering environments in which students are encouraged and provided the support needed to engage deeply with their studies and the law school experience overall.

\section{Limitations}

Although we benefit from a relatively large dataset, our ability to detect statistically significant effects may be somewhat constrained by sample size limitations, particularly in the case of our analyses of the impact of the LSSSE variables on bar performance. Insufficient sample sizes make it harder for statistical models to discern with confidence that statistically significant effects are present. This may in turn lead to "false negative" effects going undetected or understated by us.

The schools in our sample enrolled a diverse cross-section of law students that in some ways reflected the broader law school population. But some of our analyses of subsets of graduates were done using nonrepresentative data. Moreover, the self-selected nature of school participation in this study and student 
completion of the LSSSE Survey introduces elements of non-randomness that make drawing inferences risky. To help mitigate these risks, we employ fixed effects models that serve to acknowledge the nonrandomness of the data and provide estimates that theoretically account for it.

In analyzing LSAT scores, we were faced with range restriction limitations (Salkind, 2010). We were unable to observe the entire range of LSAT scores in relation to LGPA and bar performance because no school admits the entire range of LSAT scorers. Therefore, our analyses were restricted by the range of scorers that enrolled in study schools, graduated, and took the bar exam (Klieger et al., 2018). This phenomenon could have led to an understatement of the associations between LSAT score and the outcomes of interest (Gardiner, 2019). As such, our findings can only be applied to the population of law students that enroll in and graduate from law school.

Our sample naturally does not include students who entered a study law school, but did not graduate from that law school. These students may have transferred out or left law school altogether. Data pertaining to their outcomes (e.g., law school grades) are not included, potentially impacting our findings.

\section{CONCLUSION}

This study is the first multi-institutional investigation of the relationships between pre-admission factors, law school academic performance, student engagement and first-time bar exam performance. Our analyses yield various findings that in some cases align with extant research and contradict it in others. There are also findings that shed new light on previously unexplored questions. The overarching finding is a simple confirmation that what law schools do, matters. Neither pre-admission factors nor early law school performance are deterministic. There are many opportunities to change downward trajectories and position students for subsequent academic and bar exam success.

We hope that the findings presented in this report will supplement the insight, experience, and judgment of legal educators by helping inform efforts to cultivate learning environments designed to foster academic growth and bar exam preparedness.

\section{ACKNOWLEDGEMENTS}

We are extremely grateful for the advice and assistance of Tiffane Cochran, Chad Christensen, and Meera Deo. In addition, we thank Todd Nobles for his excellent research assistance.

\section{ENDNOTES}

1. The accompanying online appendix can be found at https://www.accesslex.org/research-and-data-tools-andresources/its-not-where-you-start-its-how-you-finish-predicting-law

2. We use "overreliance" to refer to law schools' heavy emphasis on UGPA and LSAT score in admissions decisions. Law schools use these metrics as a signal of who will perform better in their first year of law school. However, there are problems with this approach. First-year academic performance is only one aspect of legal education, and admissions decisions ideally would primarily consider factors that predict overall success as an attorney, especially in light of this study's argument that growth in LGPA is a powerful predictor of bar passage. As we put it below, students may perform sub-optimally early on in law school, but if they improve their grades by the time they graduate, they have a higher probability of bar exam success. Furthermore, the overreliance on LSAT scores exacerbates an existing racial disparity in average LSAT scores. Black students score about 11 points lower on the LSAT than their White and Asian counterparts, which leads to their exclusion from law schools based on a metric that does not predict lawyer success or even bar success well. See Taylor $(2015,2019)$ for an extended discussion of this dynamic.

3. As we discuss below, in models using LGPA growth as the dependent variable, we also include a control for first-semester GPA to account for the fact that a student's 1S LGPA inherently defines how much room for growth or loss they can experience.

4. These guideposts are imperfect and to some extent arbitrary, although they are based on what is commonly referred to as "Cohen's Rule of Thumb" (Cohen's $d=0.2$ [small], 0.5 [medium], and 0.8 [large]) and 
informed by Chen, Cohen, and Chen's (2010) work in the field of epidemiology. Chen et al. calculate conversions of odds ratios to Cohen's $d$ values given various levels of exposure in the nontreatment group. Given the values Chen et al. provide, assuming a rate of exposure greater than 10 percent (essentially, those in lower/higher categories of each variable would have more than a 10 percent probability of passing the bar exam), odds ratios between 1.5 and 2.0 would be considered small, between 2.0 and 4.0 medium, and greater than 4.0 large. Chen et al. do not provide conversions for ORs below 1.0, so given that a lower boundary exists for these values, we apply the inverse to the above thresholds to establish the following bounds: ORs $0.67-0.50$ small, $0.50-0.25$ medium, and less than 0.25 large.

5. To allow for comparison across effects sizes and for ease of interpretability, here and throughout, for variables that required transformation for model fit (such as UGPA), we perform the reverse transformation and then calculate the odds ratio (OR) using this coefficient, reporting that value in discussion.

6. We do not employ any models that include all LGPA variables due to the high collinearity among them. Table A.II.5 in the appendix shows the high correlation among the different LGPA variables. Utilizing models that include such highly correlated variables introduces the problem of multicollinearity. Models that violate the collinearity assumption can produce unreliable results.

7. A helpful workshop comment we received suggested that to improve one's class standing, some students might be motivated to increase their number of clinic credit hours, which are more leniently graded. This could potentially lead to an artificial inflation of LGPA growth and bias our results. However, we did not find any evidence that the number of clinic hours had any meaningful impact on bar passage or on LGPA growth.

8. Separating comparison groups by average grades allows us to examine the effect of LGPA growth on several types of students - in this case, below average, average, and above average performing students. This is useful because as Figure 5 demonstrates, the effect of LGPA growth is quite different for below-average and above-average students, allowing us to make more precise recommendations to improve bar passage rates.

9. Figures 2, 3, 4, 7, and 8 are referred to as dot-and-whisker plots. The coefficients (or, size of the effect) are represented by the dots, and the lines (or "whiskers") represent the 95 percent confidence interval. Statistically significant effects are those which do not contain zero in their confidence interval and, for ease of interpretability, are denoted in blue in Figures 7 and 8.

\section{REFERENCES}

AccessLex Institute. (2020). Legal education data deck. Retrieved from https://www.accesslex.org/research-and-data-tools-and-resources/legal-education-data-deck

Achen, C.H. (2004, November 11). Let's put garbage-can regressions and garbage-can probits where they belong [Paper presentation]. Peace Science Society annual meeting, Houston, TX, United States. Retrieved from http://www.columbia.edu/ gjw10/achen04.pdf

Aditomo, A. (2015). Students' response to academic setback: "Growth mindset" as a buffer against demotivation. International Journal of Educational Psychology, 4(2), 198-222.

Agresti, A., \& Finlay, B. (1986). Statistical methods for the social sciences. Dellen.

Albanese, M.A. (2018). The Testing Column: February 2018: The MBE Storm Surge Continues. The Bar Examiner, 87(2), 27-32.

American Bar Association. (2018). Chapter 5: Admissions and student services. In ABA standards and rules of procedure for approval of law schools 2018-2019. Retrieved from https://www.americanbar.org/content/dam/aba/publications/misc/legal_education/Standards/2018 -2019ABAStandardsforApprovalofLawSchools/2018-2019-aba-standards-chapter5.pdf

American Bar Association. (2019). ABA profile of the legal profession. Retrieved from https://www.americanbar.org/news/reporter_resources/profile-of-profession/

American Bar Association. (2019, May 6). Revisions to Standard 316: Bar passage. Retrieved from https://www.americanbar.org/content/dam/aba/administrative/legal_education_and_admissions_t o_the_bar/council_reports_and_resolutions/may19/may-7-19-316-memo.pdf

Aronson, J., Fried, C.B., \& Good, C. (2002). Reducing the effects of stereotype threat on African American college students by shaping theories of intelligence. Journal of Experimental Social Psychology, 38(2), 113-125. 
Astin, A.W. (1984). Student involvement: A development theory for higher education. Journal of College Student Development, 40, 518-529. Retrieved from

https://www.researchgate.net/publication/220017441_Student_Involvement_A_Development_Th eory_for_Higher_Education

Astin, A.W. (1991). Assessment for excellence: The philosophy and practice of assessment and evaluation in higher education. Oryx Press.

Attinasi, L.C., Jr. (1989). Getting in: Mexican Americans' perceptions of university attendance and the implications for freshman year persistence. Journal of Higher Education, 60(3), 247-277.

Austin, K.A., Christopher, C.M., \& Dickerson, D. (2016). Will I pass the bar exam?: Predicting student success using LSAT scores and law school performance. Hofstra Law Review, 45(3), 753-784.

Bess, M. (2021). Grit, growth mindset, and the path to successful lawyering. UKMC Law Review, 89(3), 493-538. https://doi.org/10.2139/ssrn.3458632

Blackwell, L.S., Trzesniewski, K.H., \& Dweck, C.S. (2007). Implicit theories of intelligence predict achievement across an adolescent transition: A longitudinal study and an intervention. Child Development, 78(1), 246-263.

Carini, R.M., Kuh, G.D., \& Klein, S.P. (2006). Student engagement and student learning: Testing the linkages. Research in Higher Education, 47, 1-32.

Chen, H., Cohen, P., \& Chen, S. (2010). How big is a big odds ratio? Interpreting the magnitudes of odds ratios in epidemiological studies. Communications in Statistics - Simulation and Computation, 39(4), 860-864. https://doi.org/10.1080/03610911003650383

Coe, A. (2017, April 10). Multistate bar exam results dive to 10-year low. Law360. Retrieved from https://www.law360.com/articles/911899/multistate-bar-exam-results-dive-to-10-year-low

Cohen, J. (1988). Statistical power analysis for the behavioral sciences. Lawrence Erlbaum Associates.

Clydesdale, T.T. (2004). A forked river runs through law school: Toward understanding race, gender, age, and related gaps in law school performance and bar passage. Law \& Social Inquiry, 29(4), 711769.

Cohen, B.H., \& Lea, R.B. (2004). Essentials of statistics for the social and behavioral sciences. Wiley.

Cronbach, L.J. (1951). Coefficient alpha and the internal structure of tests. Psychometrika, 16(3), 297334.

Currier, B. (2016). It's (appropriately) complicated: Be cautious in using LSAT scores to evaluate law schools. Syllabus, 47(2), v-vii.

Deo, M.E. (2011). The promise of Grutter: Diverse interactions at the University of Michigan Law School. Michigan Journal of Race and Law, 17(1), 63-118.

Detwiler, R.R. (2011). Assessing factors influencing student academic success in law school [Unpublished doctoral dissertation]. University of Toledo. Retrieved from http://rave.ohiolink.edu/etdc/view?acc_num=toledo1318730664

Dey, E.L. (1997). Working with low survey response rates: The efficacy of weighting adjustments. Research in Higher Education, 38(2), 215-227.

Dweck, C.S. (2000). Self-theories: Their role in motivation, personality, and development. Psychology Press.

Dweck, C.S. (2006). Mindset: The new psychology of success. Random House Publishing Group.

Farley, A.N., Swoboda, C.M., Chanvisanuruk, J., McKinley, K.M., \& Boards, A. (2018). Law student success and supports: Examining bar passage and factors that contribute to student performance. https://doi.org/10.2139/ssrn.3237546

Florio, C.M.S., \& Hoffman, S.J. (2012). Student perspectives on legal education: A longitudinal empirical evaluation. Journal of Legal Education, 62(1), 162-187.

Friedman, H.H., Herskovitz, P.J., \& Pollack, S. (1994). The biasing effects of scale-checking styles on response to a Likert scale. Proceedings of the American Statistical Association Annual Conference: Survey Research Methods, 792, 792-795. 
Gardiner, R. (2019, October 10). Understanding the impact of range restriction on LSAT correlation studies. AccessLex Institute. Retrieved from https://www.accesslex.org/xblog/understandingimpact-of-range-restriction-on-lsat-correlation-studies

George, D., \& Mallery, P. (2003). SPSS for Windows step by step: A simple guide and reference (4th ed.). Allyn \& Bacon.

Georgakopoulos, N.L. (2013). Bar passage: GPA and LSAT, not bar reviews. Indiana University Robert H. McKinney School of Law Research Paper No. 2013-30. https://doi.org/10.2139/ssrn.2308341

Gliem, J., \& Gliem, R. (2003). Calculating, interpreting, and reporting Cronbach's alpha reliability coefficient for Likert-type scales. 2003 Midwest Research to Practice Conference in Adult, Continuing, and Community Education, pp. 82-88.

Haddon, P.A., \& Post, D.W. (2006). Misuse and abuse of the LSAT: Making the case for alternative evaluative efforts and a redefinition of merit. St. John's Law Review, 80(1), 41-106.

Holmquist, K., Shultz, M., Zedeck, S., \& Oppenheimer, D. (2014). Measuring merit: The Shultz-Zedeck research on law school admissions. Journal of Legal Education, 63(4), 565-584.

Hu, S., Kuh, G.D., \& Li, S. (2008). The effects of engagement in inquiry-oriented activities on student learning and personal development. Innovative Higher Education, 33(2), 71-8.

Jellum, L., \& Reeves, E.P. (2004). Cool data on a hot issue: Empirical evidence that a law school bar support program enhances bar performance. Nevada Law Journal, 5(3), 646-683.

Jin, K.Y., \& Chen, H.F. (2020). MIMIC approach to assessing differential item functioning with control of extreme response style. Behavior Research Methods, 52(1), 23-35.

Johns, S. (2016). Empirical reflections: A statistical evaluation of bar exam program interventions. University of Louisville Law Review, 54(1), 35-72.

King, G., Keohane, R., \& Verba, S. (1994). Designing social inquiry: Scientific inference in qualitative research. Princeton University Press.

Klein, S.P. (1990). Disparities in bar exam passing rates among racial/ethnic groups: Their size, source, and implications. Thurgood Marshall Law Review, 16(3), 517-530.

Klieger, D.M., Bridgeman, B., Tannenbaum, R.J., Cline, F.A., \& Olivera-Aguilar, M. (2018). The validity of GRE general test scores for predicting academic performance at U.S. law schools. Educational Testing Service. Retrieved from https://files.eric.ed.gov/fulltext/EJ1202794.pdf

Krause, K.L., \& Coates, H. (2008). Students' engagement in first-year university. Assessment \& Evaluation in Higher Education, 33(5), 493-505.

Kuh, G.D. (2008). High impact educational practices: What they are, who has access to them, and why they matter. Association of American Colleges and Universities.

Kuh, G.D. (2009). What student affairs professionals need to know about student engagement. Journal of College Student Development, 50(6), 683-706.

Kuh, G.D. (2009). The National Survey of Student Engagement: Conceptual and empirical foundations. New Directions for Institutional Research, 2009(141), 5-20.

Kruger, J., \& Dunning, D. (1999). Unskilled and unaware of it: How difficulties in recognizing one's own incompetence lead to inflated self-assessments. Journal of Personality and Social Psychology, 77(6), 1121-1134. https://doi.org/10.1037/0022-3514.77.6.1121

Law School Admission Council. (2014). Cautionary policies concerning LSAT scores and related services. Retrieved from https://www.lsac.org/sites/default/files/media/lsat-score-cautionarypolicies_0.pdf

Law School Admission Council. (n.d.a.). Archive: 2000-2015 ABA end-of-year summaries-applicants, admitted applicants \& applications. Retrieved from https://www.lsac.org/archive-2000-2015-abaend-year-summaries-applicants-admitted-applicants-applications

Law School Admission Council. (n.d.b.). Admission trends: ABA applicants, admitted applicants \& applications. Retrieved from https://www.lsac.org/archive-2000-2015-aba-end-year-summariesapplicants-admitted-applicants-applications

Law School Survey of Student Engagement. (2020). Administering LSSSE. Retrieved from https://lssse.indiana.edu/administering/ 
Law School Survey of Student Engagement. (2012). Lessons from law students on legal educationannual results 2012. Indiana University Center for Postsecondary Research.

Law School Survey of Student Engagement. (2020). LSSSE Survey. Retrieved from https://ssse.indiana.edu/about-lssse-surveys/

Likert, R. (1931). A technique for the measurement of attitudes. Archives of Psychology, 22(140), 1-55.

Markovic, M., \& Plickert, G. (2019). The paradox of minority attorney satisfaction. International Review of Law and Economics, 60, 105859. https://doi.org/10.1016/j.irle.2019.105859

Marks, A.B., \& Moss, S.A. (2016). What predicts law student success: A longitudinal study correlating law student applicant data and law school outcomes. Journal of Empirical Legal Studies, 13(2), 205-265.

McCormick, A.C., Kinzie, J., \& Gonyea, R.M. (2013). Student engagement: Bridging research and practice to improve the quality of undergraduate education. In M.B. Paulsen (Ed.), Higher education: Handbook of theory and research (pp. 47-92). Springer.

National Conference of Bar Examiners. (2019, August 20). Impact of adoption of the Uniform Bar Examination in New York. Retrieved from https://www.nybarexam.org/UBEReport/NY\%20UBE\%20Adoption\%20Part\%202\%20Study.pdf

Pascarella, E.T. (1980). Student-faculty informal contact and college outcomes. Review of Educational Research, 50(4), 545-595.

Pratt, C.D. (2008). Way to represent: The role of black lawyers in contemporary American democracy. Fordham Law Review, 77(4), 1409-1434.

Quaye, S.J., \& Harper, S.R. (Eds.). (2014). Student engagement in higher education: Theoretical perspectives and practical approaches for diverse populations. Routledge.

Quintanilla, V.D., \& Erman, S. (2020). Productive mindset interventions mitigate psychological friction and improve well-being for bar exam takers. Raising the Bar, 3(1), 7-9.

Randall, V.R. (2006). The misuses of the LSAT: Discrimination against blacks and other minorities in law school admissions. St. John's Law Review, 80(1), 107-152.

Rocconi, L., Taylor, A., Haeger, H., Zilvinskis, J., \& Christensen, C. (2019). Beyond the numbers: An examination of diverse interactions in law school. Journal of Diversity in Higher Education, 12(1), 27-37.

Rhode, D.L. (2015, May 27). Law is the least diverse profession in the nation. And lawyers aren't doing enough to change that. The Washington Post. Retrieved from

https://www.washingtonpost.com/posteverything/wp/2015/05/27/law-is-the-least-diverseprofession-in-the-nation-and-lawyers-arent-doing-enough-to-change-that/?hpid=z11

Salkind, N.J. (2010). Encyclopedia of research design (Vols. 1-0). SAGE Publications, Inc. http://doi.org/10.4135/9781412961288

Sander, R.H. (2019). Are law schools engines of inequality. Journal of Law and Education, 48(2), 243263.

Shultz, M.M., \& Zedeck, S. (2011). Predicting lawyer effectiveness: Broadening the basis for law school admission decisions. Law \& Social Inquiry, 36(3), 620-661.

Shultz, M.M., \& Zedeck, S. (2012). Admission to law school: New measures. Educational Psychologist, 47(1), 51-65.

Shapcott, S., Davis, S., \& Hanson, L. (2017). The jury is in: Law schools foster students' fixed mindsets. Law \& Psychology Review, 42, 1-34.

Silver, C., Rocconi, L., Haeger, H., \& Watkins, L. (2013). Gaining from the system: Lessons from the Law School Survey of Student Engagement about student development in law school. University of St. Thomas Law Journal, 10(1), 286-316.

Sperling, C., \& Shapcott, S. (2012). Fixing students' fixed mindsets: Paving the way for meaningful assessment. Legal Writing, 18, 39-84.

Spitzer, B., \& Aronson, J. (2015). Minding and mending the gap: Social psychological interventions to reduce educational disparities. Journal of Educational Psychology, 85(1), 1-18. 
State Bar of California. (2019, December 20). General statistics report July 2019 California bar examination. Retrieved from http://www.calbar.ca.gov/Portals/0/documents/July2019-CBXStatistics.pdf

Taylor, A.N. (2019). The marginalization of black aspiring lawyers. FIU Law Review, 13(3), 489-512.

Taylor, A.N. (2015). Diversity as a law school survival strategy. Saint Louis U. Legal Studies Research Paper No. 2015-1.

Taylor, A.N. (2014). Diversity as a law school survival strategy. St. Louis University Law Journal, 59(2), 321-384.

Taylor, A.N., \& Christensen, C. (2017). Law school scholarship policies: Engines of inequity (LSSSE Annual Results 2016). Indiana University Center for Postsecondary Research.

The Bar Examiner. (n.d.). 2018 First-Time Exam Takers and Repeaters from ABA-Approved Law Schools [Dataset]. Retrieved from https://thebarexaminer.org/statistics/2018-statistics/2018-first-timeexam-takers-and-repeaters-from-aba-approved-law-schools/

The Bar Examiner. (n.d.). 2019 First-Time Exam Takers and Repeaters from ABA-Approved Law Schools [Dataset]. Retrieved from https://thebarexaminer.org/2019-statistics/2019-first-time-exam-takersand-repeaters-from-aba-approved-law-schools/

Thomas, D. (2003). Predicting law school academic performance from LSAT scores and undergraduate grade point averages: A comprehensive study. Arizona State Law Journal, 35(3), 1007-1028.

Tinto, V. (1975). Dropouts from higher education: A theoretical synthesis of recent research. Review of Educational Research, 45(1), 89-125.

Trujillo, L.A. (2007). The relationship between law school and the bar exam: A look at assessment and student success. University of Colorado Law Review, 78(1), 69-114.

Ward, S.F. (2018, November 19). Lowest bar pass rate for California in 67 years; other states see drop, too. ABA Journal. Retrieved from

http://www.abajournal.com/news/article/lowest_bar_pass_rate_for_california_in_67_years_other states_see_drop_too

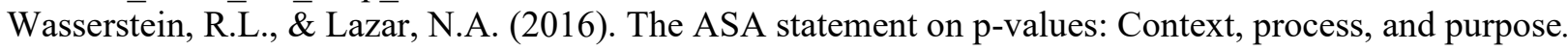 The American Statistician, 70(2), 129-133. https://doi.org/10.1080/00031305.2016.1154108

Wasserstein, R.L., Schirm, A.L., \& Lazar, N.A. (2019). Moving to a world beyond " $p<0.05$ ". The American Statistician, 73(sup1), 1-19. https://doi.org/10.1080/00031305.2019.1583913

Wightman, L.F. (1997). The threat to diversity in legal education: An empirical analysis of the consequences of abandoning race as a factor in law school admission decisions. New York University Law Review, 72(1), 1-53.

Wightman, L.F., \& Ramsey, H. (1998). LSAC national longitudinal bar passage study. Law School Admission Council. 


\section{APPENDIX}

TABLE A.1

FULL TABLE OF EFFECTS OF LSAT, UGPA, AND CONTROL VARIABLES ON THREE LGPA MEASURES COEFFICIENTS AND 95 PERCENT CONFIDENCE INTERVALS

\begin{tabular}{|c|c|c|c|c|}
\hline & \multicolumn{4}{|c|}{ Law School GPA: } \\
\hline & $\begin{array}{l}\text { First-Semester } \\
\quad(\mathrm{n}=3,938)\end{array}$ & $\begin{array}{l}\text { First-Year } \\
(\mathrm{n}=3,941)\end{array}$ & $\begin{array}{c}\text { Final } \\
(\mathrm{n}=4,223)\end{array}$ & $\begin{array}{c}\text { Growth } \\
(\mathrm{n}=3,938)\end{array}$ \\
\hline \multirow{2}{*}{ LSAT } & $0.380^{* * *}$ & $0.393^{* * *}$ & $0.340^{* * *}$ & $0.055^{* * *}$ \\
\hline & $(0.350,0.410)$ & $(0.363,0.422)$ & $(0.312,0.368)$ & $(0.036,0.074)$ \\
\hline \multirow{2}{*}{ UGPA } & $0.268^{* * *}$ & $0.291^{* * *}$ & $0.309^{* * *}$ & $0.112^{* * *}$ \\
\hline & $(0.238,0.297)$ & $(0.262,0.320)$ & $(0.282,0.337)$ & $(0.094,0.130)$ \\
\hline \multirow{2}{*}{ Male } & $-0.071^{* *}$ & $-0.079^{* * *}$ & $-0.074^{* * *}$ & $-0.042^{* *}$ \\
\hline & $(-0.128,-0.014)$ & $(-0.135,-0.023)$ & $(-0.128,-0.019)$ & $(-0.076,-0.008)$ \\
\hline \multirow{2}{*}{ Asian } & $-0.311^{* * *}$ & $-0.370^{* * *}$ & $-0.355^{* * *}$ & $-0.131^{* * *}$ \\
\hline & $(-0.418,-0.205)$ & $(-0.475,-0.266)$ & $(-0.454,-0.256)$ & $(-0.194,-0.068)$ \\
\hline \multirow{2}{*}{ Black } & $-0.175^{* * *}$ & $-0.250^{* * *}$ & $-0.350^{* * *}$ & $-0.200^{* * *}$ \\
\hline & $(-0.290,-0.060)$ & $(-0.363,-0.138)$ & $(-0.455,-0.245)$ & $(-0.268,-0.132)$ \\
\hline \multirow{2}{*}{ Hispanic } & $-0.149^{* * *}$ & $-0.187^{* * *}$ & $-0.203^{* * *}$ & $-0.101^{* * *}$ \\
\hline & $(-0.241,-0.056)$ & $(-0.278,-0.097)$ & $(-0.290,-0.116)$ & $(-0.156,-0.047)$ \\
\hline \multirow{2}{*}{ All Other Races } & $-0.360^{* * *}$ & $-0.368^{* * *}$ & $-0.324^{* * *}$ & -0.085 \\
\hline & $(-0.566,-0.155)$ & $(-0.568,-0.168)$ & $(-0.512,-0.136)$ & $(-0.207,0.037)$ \\
\hline \multirow{2}{*}{ Age: $35+$} & $-0.201^{* * *}$ & $-0.146^{* *}$ & -0.020 & $0.091^{* * *}$ \\
\hline & $(-0.316,-0.087)$ & $(-0.258,-0.034)$ & $(-0.125,0.084)$ & $(0.023,0.159)$ \\
\hline \multirow{2}{*}{ Graduation Year: 2019} & 0.011 & 0.045 & $0.053^{*}$ & $0.058^{* * *}$ \\
\hline & $(-0.046,0.068)$ & $(-0.011,0.101)$ & $(-0.001,0.108)$ & $(0.024,0.092)$ \\
\hline \multirow{2}{*}{ First-Semester LGPA } & & & & $-0.224^{* * *}$ \\
\hline & & & & $(-0.243,-0.205)$ \\
\hline \multirow{2}{*}{ Transfer Student } & & 0.175 & $0.284^{* * *}$ & \\
\hline & & $(-0.347,0.696)$ & $(0.172,0.396)$ & \\
\hline Log Likelihood & $-5,063.274$ & -4989.333 & $-5,351.400$ & $-3,001.225$ \\
\hline Akaike Inf. Crit. & $10,146.550$ & $10,000.670$ & $10,724.800$ & $6,024.451$ \\
\hline Bayesian Inf. Crit. & $10,209.330$ & $10,069.740$ & $10,794.630$ & $6,093.513$ \\
\hline
\end{tabular}

Note: ${ }^{*} \mathrm{p}<0.1 ;{ }^{* *} \mathrm{p}<0.05 ;{ }^{* * *} \mathrm{p}<0.01$; law school GPAs, LSAT scores, and UGPAs have been standardized within each school. 


\section{FULL TABLE OF EFFECTS OF ACADEMIC PERFORMANCE AND CONTROL VARIABLES ON BAR PASSAGE ODDS RATIOS AND 95 PERCENT CONFIDENCE INTERVALS}

\begin{tabular}{|c|c|c|c|c|c|}
\hline & & & imary Predictor & & \\
\hline & $\begin{array}{l}\text { LSAT and } \\
\text { UGPA } \\
(\mathrm{n}=3,975)\end{array}$ & $\begin{array}{c}\text { First-Semester } \\
\text { LGPA } \\
(\mathrm{n}=3,721)\end{array}$ & $\begin{array}{c}\text { First-Year } \\
\text { LGPA } \\
(\mathrm{n}=3,725)\end{array}$ & $\begin{array}{c}\text { Final LGPA } \\
(\mathrm{n}=3,975)\end{array}$ & $\begin{array}{l}\text { LGPA Growth } \\
\qquad(\mathrm{n}=3,721)\end{array}$ \\
\hline First-Semester LGPA & & $\begin{array}{c}3.385^{* * *} \\
(2.968,3.755)\end{array}$ & & & $\begin{array}{c}5.971^{* * *} \\
(5.131,6.950)\end{array}$ \\
\hline First-Year LGPA & & & $\begin{array}{c}4.235^{\text {*** }} \\
(3.718,4.823)\end{array}$ & & \\
\hline Final LGPA & & & & $\begin{array}{c}5.557^{* * *} \\
(4.840,6.381)\end{array}$ & \\
\hline LGPA Growth & & & & & $\begin{array}{c}5.435^{* * *} \\
(4.454,6.632)\end{array}$ \\
\hline LSAT Score & $\begin{array}{c}1.708^{* * *} \\
(1.562,1.868)\end{array}$ & $\begin{array}{c}1.257^{* * *} \\
(1.126,1.404)\end{array}$ & $\begin{array}{c}1.189^{* * *} \\
(1.061,1.333)\end{array}$ & $\begin{array}{c}1.207^{* * *} \\
(1.084,1.344)\end{array}$ & $\begin{array}{c}1.166^{* *} \\
(1.035,1.313)\end{array}$ \\
\hline UGPA & $\begin{array}{c}1.442^{* * *} \\
(1.328,1.567)\end{array}$ & $\begin{array}{c}1.202^{* * *} \\
(1.088,1.327)\end{array}$ & $\begin{array}{c}1.140^{* *} \\
(1.029,1.263)\end{array}$ & $\begin{array}{c}1.018 \\
(0.921,1.125)\end{array}$ & $\begin{array}{c}1.015 \\
(0.911,1.131)\end{array}$ \\
\hline Male & $\begin{array}{c}1.089 \\
(0.922,1.287)\end{array}$ & $\begin{array}{c}1.172 \\
(0.968,1.419)\end{array}$ & $\begin{array}{c}1.195^{*} \\
(0.983,1.453)\end{array}$ & $\begin{array}{c}1.190^{*} \\
(0.981,1.445)\end{array}$ & $\begin{array}{c}1.291^{* *} \\
(1.052,1.583)\end{array}$ \\
\hline Asian & $\begin{array}{c}0.628^{* * *} \\
(0.475,0.829)\end{array}$ & $\begin{array}{c}0.834 \\
(0.605,1.149)\end{array}$ & $\begin{array}{c}0.896 \\
(0.644,1.245)\end{array}$ & $\begin{array}{c}0.860 \\
(0.622,1.188)\end{array}$ & $\begin{array}{c}0.962 \\
(0.684,1.354)\end{array}$ \\
\hline Black & $\begin{array}{c}0.645^{* * *} \\
(0.484,0.860)\end{array}$ & $\begin{array}{c}0.772 \\
(0.552,1.081)\end{array}$ & $\begin{array}{c}0.912 \\
(0.644,1.291)\end{array}$ & $\begin{array}{c}0.960 \\
(0.689,1.338)\end{array}$ & $\begin{array}{c}1.050 \\
(0.734,1.504)\end{array}$ \\
\hline Hispanic & $\begin{array}{c}0.804^{*} \\
(0.629,1.029)\end{array}$ & $\begin{array}{c}0.940 \\
(0.710,1.244)\end{array}$ & $\begin{array}{c}1.005 \\
(0.754,1.340)\end{array}$ & $\begin{array}{c}1.039 \\
(0.783,1.381)\end{array}$ & $\begin{array}{c}1.082 \\
(0.804,1.456)\end{array}$ \\
\hline All Other Races & $\begin{array}{c}0.392^{* * *} \\
(0.228,0.673)\end{array}$ & $\begin{array}{c}0.590 \\
(0.301,1.155)\end{array}$ & $\begin{array}{c}0.579 \\
(0.292,1.146)\end{array}$ & $\begin{array}{c}0.403^{* * *} \\
(0.210,0.773)\end{array}$ & $\begin{array}{c}0.500^{*} \\
(0.243,1.026)\end{array}$ \\
\hline Age: 35 or Older & $\begin{array}{c}0.756^{*} \\
(0.560,1.021)\end{array}$ & $\begin{array}{c}0.901 \\
(0.631,1.287)\end{array}$ & $\begin{array}{c}0.882 \\
(0.612,1.272)\end{array}$ & $\begin{array}{c}0.662^{* *} \\
(0.469,0.935)\end{array}$ & $\begin{array}{c}0.750 \\
(0.515,1.093)\end{array}$ \\
\hline California Bar Taker & $\begin{array}{c}0.214^{* * *} \\
(0.106,0.431)\end{array}$ & $\begin{array}{c}0.194^{* * *} \\
(0.086,0.437)\end{array}$ & $\begin{array}{c}0.221^{* * *} \\
(0.098,0.500)\end{array}$ & $\begin{array}{c}0.146^{* * *} \\
(0.066,0.322)\end{array}$ & $\begin{array}{c}0.155^{\text {*** }} \\
(0.065,0.373)\end{array}$ \\
\hline Log Likelihood & $-1,784.700$ & $-1,382.665$ & $-1,315.750$ & $-1,336.424$ & $-1,213.998$ \\
\hline Akaike Inf. Crit. & $3,587.399$ & $2,785.33$ & $2,651.499$ & $2,692.847$ & $2,449.997$ \\
\hline Bayesian Inf. Crit. & $3,641.481$ & $2,844.835$ & $2,711.015$ & $2,752.938$ & $2,515.452$ \\
\hline
\end{tabular}


TABLE A.3

FULL TABLE OF EFFECTS OF STUDENT ENGAGEMENT FACTORS AND CONTROL VARIABLES ON 3L LGPA COEFFICIENTS AND 95 PERCENT CONFIDENCE INTERVALS

\begin{tabular}{|c|c|c|c|c|}
\hline & \multicolumn{4}{|c|}{ Student Engagement Variables Included: } \\
\hline & $\begin{array}{c}\text { LSSSE } \\
\text { Engagement } \\
\text { Indicators Only } \\
(\mathrm{n}=1,461) \\
\end{array}$ & $\begin{array}{c}\text { School-Related } \\
\text { Factors } \\
(\mathrm{n}=1,459)\end{array}$ & $\begin{array}{c}\text { Student-Centered } \\
\text { Factors } \\
(\mathrm{n}=1,413)\end{array}$ & $\begin{array}{l}\text { All Student } \\
\text { Engagement } \\
\text { Factors } \\
(\mathrm{n}=1,288) \\
\end{array}$ \\
\hline \multirow{2}{*}{$\begin{array}{l}\text { Learning to think like a } \\
\text { lawyer: Quite a bit }\end{array}$} & $0.139^{*}$ & & & 0.016 \\
\hline & $(-0.004,0.282)$ & & & $(-0.140,0.172)$ \\
\hline \multirow{2}{*}{$\begin{array}{l}\text { Learning to think like a } \\
\text { lawyer: Very much }\end{array}$} & $0.221^{* * *}$ & & & 0.041 \\
\hline & $(0.075,0.367)$ & & & $(-0.126,0.209)$ \\
\hline \multirow[t]{2}{*}{ Student advising: Satisfied } & -0.030 & & & -0.096 \\
\hline & $(-0.139,0.079)$ & & & $(-0.214,0.021)$ \\
\hline \multirow{2}{*}{$\begin{array}{l}\text { Student advising: Very } \\
\text { satisfied }\end{array}$} & 0.078 & & & -0.125 \\
\hline & $(-0.085,0.240)$ & & & $(-0.301,0.052)$ \\
\hline \multirow{2}{*}{$\begin{array}{l}\text { Student-faculty interaction: } \\
\text { Often }\end{array}$} & $0.101^{*}$ & & & -0.025 \\
\hline & $(-0.001,0.203)$ & & & $(-0.137,0.088)$ \\
\hline \multirow{2}{*}{$\begin{array}{l}\text { Student-faculty interaction: } \\
\text { Very often }\end{array}$} & $0.235^{* * *}$ & & & 0.025 \\
\hline & $(0.082,0.386)$ & & & $(-0.147,0.198)$ \\
\hline \multirow{2}{*}{$\begin{array}{l}\text { Law school environment: } \\
\text { Often }\end{array}$} & 0.068 & & & -0.023 \\
\hline & $(-0.042,0.178)$ & & & $(-0.151,0.105)$ \\
\hline \multirow{2}{*}{$\begin{array}{l}\text { Law school environment: } \\
\text { Very often }\end{array}$} & -0.064 & & & -0.123 \\
\hline & $(-0.238,0.109)$ & & & $(-0.341,0.095)$ \\
\hline \multirow{2}{*}{$\begin{array}{l}\text { Emphasis on academics: } \\
\text { Quite a bit }\end{array}$} & & $-0.113^{*}$ & & -0.083 \\
\hline & & $(-0.246,0.019)$ & & $(-0.227,0.061)$ \\
\hline \multirow{2}{*}{$\begin{array}{l}\text { Emphasis on academics: } \\
\text { Very much }\end{array}$} & & $-0.179^{*}$ & & -0.103 \\
\hline & & $(-0.360,-0.001)$ & & $(-0.317,0.111)$ \\
\hline \multirow[t]{2}{*}{ Supportive relationships } & & $0.018^{* *}$ & & 0.014 \\
\hline & & $(0.003,0.034)$ & & $(-0.003,0.031)$ \\
\hline \multirow{2}{*}{$\begin{array}{l}\text { Acquired broad legal } \\
\text { education: Quite a bit }\end{array}$} & & $0.164^{* *}$ & & 0.104 \\
\hline & & $(0.015,0.314)$ & & $(-0.056,0.263)$ \\
\hline \multirow{2}{*}{$\begin{array}{l}\text { Acquired broad legal } \\
\text { education: Very much }\end{array}$} & & 0.105 & & 0.014 \\
\hline & & $(-0.059,0.270)$ & & $(-0.161,0.188)$ \\
\hline \multirow{2}{*}{$\begin{array}{l}\text { Developed practical skills: } \\
\text { Quite a bit }\end{array}$} & & 0.017 & & -0.018 \\
\hline & & $(-0.113,0.147)$ & & $(-0.158,0.122)$ \\
\hline \multirow{2}{*}{$\begin{array}{l}\text { Developed practical skills: } \\
\text { Very much }\end{array}$} & & 0.096 & & 0.030 \\
\hline & & $(-0.065,0.257)$ & & $(-0.145,0.205)$ \\
\hline \multirow{2}{*}{$\begin{array}{l}\text { Diverse knowledge } \\
\text { displayed: Often }\end{array}$} & & $0.094^{*}$ & & 0.002 \\
\hline & & $(-0.016,0.205)$ & & $(-0.121,0.118)$ \\
\hline
\end{tabular}




\begin{tabular}{|c|c|c|c|}
\hline $\begin{array}{l}\text { Diverse knowledge } \\
\text { displayed: Very often }\end{array}$ & $\begin{array}{c}0.068 \\
(-0.073,0.209)\end{array}$ & & $\begin{array}{c}-0.79^{* *} \\
(-0.338,-0.020)\end{array}$ \\
\hline School satisfaction: & $0.170^{* *}$ & & $0.218^{* * *}$ \\
\hline Satisfied & $(0.021,0.318)$ & & $(0.062,0.375)$ \\
\hline $\begin{array}{l}\text { School satisfaction: Very } \\
\text { satisfied }\end{array}$ & $\begin{array}{c}0.388^{* * *} \\
(0.209,0.566)\end{array}$ & & $\begin{array}{c}0.427^{* * *} \\
(0.236,0.618)\end{array}$ \\
\hline $\begin{array}{l}\text { Amount of law school } \\
\text { debt:20-100k }\end{array}$ & $\begin{array}{c}-0.097 \\
(-0.219,0.025)\end{array}$ & & $\begin{array}{c}-0.057 \\
(-0.183,0.069)\end{array}$ \\
\hline $\begin{array}{l}\text { Amount of law school } \\
\text { debt:100k+ }\end{array}$ & $\begin{array}{c}-0.174^{* * *} \\
(-0.298,-0.049)\end{array}$ & & $\begin{array}{c}-0.110^{*} \\
(-0.240,0.020)\end{array}$ \\
\hline $\begin{array}{l}\text { Coursework difficulty: } \\
\text { Challenging }\end{array}$ & & $\begin{array}{c}0.215^{* * *} \\
(0.109,0.320)\end{array}$ & $\begin{array}{c}0.167^{* * *} \\
(0.050,0.283)\end{array}$ \\
\hline $\begin{array}{l}\text { Coursework difficulty: } \\
\text { Very Challenging }\end{array}$ & & $\begin{array}{c}0.315^{* * *} \\
(0.156,0.475)\end{array}$ & $\begin{array}{c}0.288^{* * *} \\
(0.111,0.466)\end{array}$ \\
\hline Class participation: Often & & $\begin{array}{c}0.187^{* * *} \\
(0.080,0.295)\end{array}$ & $\begin{array}{c}0.174^{* * *} \\
(0.058,0.290)\end{array}$ \\
\hline $\begin{array}{l}\text { Class participation: Very } \\
\text { Often }\end{array}$ & & $\begin{array}{c}0.445^{* * *} \\
(0.325,0.564)\end{array}$ & $\begin{array}{c}0.421^{* * *} \\
(0.290,0.551)\end{array}$ \\
\hline $\begin{array}{l}\text { Preparation for class } \\
\text { (hrs/wk): } 21-30 \mathrm{hrs}\end{array}$ & & $\begin{array}{c}-0.119^{* *} \\
(-0.233,-0.006)\end{array}$ & $\begin{array}{c}-0.119^{*} \\
(-0.237,-0.000)\end{array}$ \\
\hline $\begin{array}{l}\text { Preparation for class: } 31+ \\
\text { hrs }\end{array}$ & & $\begin{array}{c}-0.132^{* *} \\
(-0.246,-0.019)\end{array}$ & $\begin{array}{c}-0.128^{* *} \\
(-0.249,-0.007)\end{array}$ \\
\hline $\begin{array}{l}\text { Came to class unprepared: } \\
\text { Sometimes }\end{array}$ & & $\begin{array}{c}0.200^{* * *} \\
(0.076,0.324)\end{array}$ & $\begin{array}{c}0.180^{* * *} \\
(0.050,0.310)\end{array}$ \\
\hline $\begin{array}{l}\text { Came to class unprepared: } \\
\text { Never }\end{array}$ & & $\begin{array}{c}0.432^{* * *} \\
(0.276,0.588)\end{array}$ & $\begin{array}{c}0.435^{* * *} \\
(0.272,0.599)\end{array}$ \\
\hline $\begin{array}{l}\text { Collaboration: Often/Very } \\
\text { often }\end{array}$ & & $\begin{array}{c}0.065 \\
(-0.032,0.162)\end{array}$ & $\begin{array}{c}0.079 \\
(-0.030,0.187)\end{array}$ \\
\hline $\begin{array}{l}\text { Extracurricular legal } \\
\text { experience (hrs/wk): 1-10 } \\
\text { hrs }\end{array}$ & & $\begin{array}{c}-0.032 \\
(-0.1450,0.085)\end{array}$ & $\begin{array}{c}-0.040 \\
(-0.163,0.084)\end{array}$ \\
\hline $\begin{array}{l}\text { Extracurricular legal } \\
\text { experience: } 11-20 \mathrm{hrs}\end{array}$ & & $\begin{array}{c}-0.085 \\
(-0.208,0.038)\end{array}$ & $\begin{array}{c}-0.105 \\
(-0.232,0.023)\end{array}$ \\
\hline $\begin{array}{l}\text { Extracurricular legal } \\
\text { experience: } 21+\mathrm{hrs}\end{array}$ & & $\begin{array}{c}-0.107 \\
(-0.243,0.030)\end{array}$ & $\begin{array}{c}-0.094 \\
(-0.238,0.050)\end{array}$ \\
\hline $\begin{array}{l}\text { Self-Care (hrs/wk): 11-25 } \\
\text { hrs }\end{array}$ & & $\begin{array}{c}-0.081 \\
(-0.184,0.021)\end{array}$ & $\begin{array}{c}-0.077 \\
(-0.186,0.033)\end{array}$ \\
\hline Self-Care: $26+$ hrs & & $\begin{array}{c}-0.072 \\
(-0.222,0.078)\end{array}$ & $\begin{array}{c}-0.047 \\
(-0.207,0.113)\end{array}$ \\
\hline $\begin{array}{l}\text { Other responsibilities } \\
\text { (hrs/wk): 6-20 hrs }\end{array}$ & & $\begin{array}{c}0.004 \\
(-0.103,0.095)\end{array}$ & $\begin{array}{c}-0.003 \\
(-0.107,0.100)\end{array}$ \\
\hline
\end{tabular}




\begin{tabular}{|c|c|c|c|c|}
\hline $\begin{array}{l}\text { Other responsibilities: } 21+ \\
\text { hrs }\end{array}$ & & & $\begin{array}{c}-0.203^{* * *} \\
(-0.338,-0.069)\end{array}$ & $\begin{array}{c}-0.188^{* *} \\
(-0.331,-0.044)\end{array}$ \\
\hline LSAT score & $\begin{array}{c}0.293^{* * *} \\
(0.244,0.342)\end{array}$ & $\begin{array}{c}0.283^{* * *} \\
(0.234,0.333)\end{array}$ & $\begin{array}{c}0.288^{* * *} \\
(0.239,0.338)\end{array}$ & $\begin{array}{c}0.286^{* * *} \\
(0.234,0.337)\end{array}$ \\
\hline UGPA & $\begin{array}{c}0.269^{* * *} \\
(0.222,0.316)\end{array}$ & $\begin{array}{c}0.285^{* * *} \\
(0.238,0.331)\end{array}$ & $\begin{array}{c}0.257^{* * *} \\
(0.210,0.303)\end{array}$ & $\begin{array}{c}0.254^{* * *} \\
(0.204,0.304)\end{array}$ \\
\hline Male & & & & $\begin{array}{c}-0.102^{* *} \\
(-0.201,-0.002)\end{array}$ \\
\hline Asian & $\begin{array}{c}-0.280^{* * *} \\
(-0.463,-0.097)\end{array}$ & $\begin{array}{c}-0.244^{* *} \\
(-0.433,-0.055)\end{array}$ & $\begin{array}{c}-0.231^{* *} \\
(-0.419,-0.043)\end{array}$ & $\begin{array}{c}-0.184^{*} \\
(-0.380,0.012)\end{array}$ \\
\hline Black & $\begin{array}{c}-0.311^{* * *} \\
(-0.514,-0.109)\end{array}$ & $\begin{array}{c}-0.267^{* *} \\
(-0.471,-0.063)\end{array}$ & $\begin{array}{c}-0.293^{* * *} \\
(-0.489,-0.096)\end{array}$ & $\begin{array}{c}--0.331^{* * *} \\
(-0.543,-0.119)\end{array}$ \\
\hline Hispanic & $\begin{array}{c}-0.215^{* *} \\
(-0.379,-0.051)\end{array}$ & $\begin{array}{c}-0.219^{* *} \\
(-0.385,-0.052)\end{array}$ & $\begin{array}{c}-0.171^{* *} \\
(-0.333,-0.008)\end{array}$ & $\begin{array}{c}0.175^{* *} \\
(-0.344,-0.007)\end{array}$ \\
\hline All Other Races & $\begin{array}{c}-0.235 \\
(-0.546,0.077)\end{array}$ & $\begin{array}{c}-0.201 \\
(-0.520,0.118)\end{array}$ & $\begin{array}{c}-0.180 \\
(-0.502,0.143)\end{array}$ & $\begin{array}{c}-0.149 \\
(-0.479,0.181)\end{array}$ \\
\hline Age: 35 or older & & & $\begin{array}{c}-0.214^{* *} \\
(-0.387,-0.042)\end{array}$ & $\begin{array}{c}-0.233^{* *} \\
(-0.420,-0.047)\end{array}$ \\
\hline First generation law student & $\begin{array}{c}-0.068 \\
(-0.173,0.038)\end{array}$ & $\begin{array}{c}-0.065 \\
(-0.170,0.040)\end{array}$ & $\begin{array}{c}-0.050 \\
(-0.156,0.056)\end{array}$ & $\begin{array}{c}-0.063 \\
(-0.175,0.048)\end{array}$ \\
\hline Graduation Year: 2019 & & & & $\begin{array}{c}0.028 \\
(-0.072,0.128)\end{array}$ \\
\hline $\begin{array}{l}\text { Amount of Law School } \\
\text { Debt (control) }\end{array}$ & $\begin{array}{c}-0.028^{* * *} \\
(-0.043,-0.014) \\
\end{array}$ & & $\begin{array}{c}-0.019^{* * *} \\
(-0.033,-0.005) \\
\end{array}$ & \\
\hline Log Likelihood & $-1,843.531$ & $-1,832.297$ & $-1,730.593$ & $-1,549.844$ \\
\hline Akaike Inf. Crit. & $3,721.061$ & $3,706.594$ & $3,513.185$ & $3,195.689$ \\
\hline Bayesian Inf. Crit. & $3,810.938$ & $3,817.589$ & $3,649.775$ & $3,443.409$ \\
\hline
\end{tabular}

Note: ${ }^{*} \mathrm{p}<0.10 ;{ }^{* *} \mathrm{p}<0.05 ;{ }^{* * *} \mathrm{p}<0.01 ; 3 \mathrm{~L}$ LGPA, LSAT score, and UGPA are standardized within each school. 
TABLE A.4

FULL TABLE OF EFFECTS OF STUDENT ENGAGEMENT FACTORS AND CONTROL VARIABLES ON ODDS OF BAR PASSAGE ODDS RATIOS AND 95 PERCENT CONFIDENCE INTERVALS

\begin{tabular}{|c|c|c|c|}
\hline & \multicolumn{3}{|c|}{ Student engagement variables included: } \\
\hline & $\begin{array}{c}\text { LSSSE } \\
\text { Engagement } \\
\text { Indicators Only } \\
(\mathrm{n}=1,451)\end{array}$ & $\begin{array}{l}\text { School-Related } \\
\text { Factors } \\
(n=1,408)\end{array}$ & $\begin{array}{c}\text { Student-Centered } \\
\text { Factors } \\
(\mathrm{n}=1,366)\end{array}$ \\
\hline $\begin{array}{l}\text { Learning to think like a lawyer: Quite a } \\
\text { bit }\end{array}$ & $\begin{array}{c}1.061 \\
(0.683,1.647)\end{array}$ & & \\
\hline $\begin{array}{l}\text { Learning to think like a lawyer: Very } \\
\text { much }\end{array}$ & $\begin{array}{c}0.939 \\
(0.598,1.474)\end{array}$ & & \\
\hline Student advising: Satisfied & $\begin{array}{c}1.024 \\
(0.726,1.445)\end{array}$ & & \\
\hline Student advising: Very satisfied & $\begin{array}{c}0.910 \\
(0.553,1.498)\end{array}$ & & \\
\hline Student-faculty interaction: Often & $\begin{array}{c}0.967 \\
(0.705,1.327)\end{array}$ & & \\
\hline Student-faculty interaction: Very often & $\begin{array}{c}0.954 \\
(0.595,1.531)\end{array}$ & & \\
\hline Law school environment: Often & $\begin{array}{c}1.060 \\
(0.750,1.498)\end{array}$ & & \\
\hline Law school environment: Very often & $\begin{array}{c}1.062 \\
(0.621,1.815)\end{array}$ & & \\
\hline Emphasis on academics: Quite a bit & & $\begin{array}{c}0.866 \\
(0.567,1.322)\end{array}$ & \\
\hline Emphasis on academics: Very much & & $\begin{array}{c}0.610^{*} \\
(0.343,1.086)\end{array}$ & \\
\hline Supportive relationships & & $\begin{array}{c}1.012 \\
(0.963,1.062)\end{array}$ & \\
\hline $\begin{array}{l}\text { Acquired broad legal education: Quite a } \\
\text { bit }\end{array}$ & & $\begin{array}{c}1.519^{*} \\
(0.964,2.393)\end{array}$ & \\
\hline $\begin{array}{l}\text { Acquired broad legal education: Very } \\
\text { much }\end{array}$ & & $\begin{array}{c}1.238 \\
(0.747,2.051)\end{array}$ & \\
\hline Practical skills development: Quite a bit & & $\begin{array}{c}1.405^{*} \\
(0.945,2.090)\end{array}$ & \\
\hline Practical skills development: Very much & & $\begin{array}{c}1.560^{*} \\
(0.941,2.588)\end{array}$ & \\
\hline Diverse knowledge displayed: Often & & $\begin{array}{c}1.166 \\
(0.825,1.647)\end{array}$ & \\
\hline
\end{tabular}




\begin{tabular}{|c|c|c|}
\hline Diverse knowledge displayed: Very often & $\begin{array}{c}1.120 \\
(0.709,1.769)\end{array}$ & \\
\hline School satisfaction: Satisfied & $\begin{array}{c}0.922 \\
(0.584,1.456)\end{array}$ & \\
\hline School satisfaction: Very satisfied & $\begin{array}{c}1.310 \\
(0.746,2.303)\end{array}$ & \\
\hline Amount of law school debt:20-100k & $\begin{array}{c}0.972 \\
(0.632,1.495)\end{array}$ & \\
\hline Amount of law school debt: $100 \mathrm{k}+$ & $\begin{array}{c}0.890 \\
(0.598,1.325)\end{array}$ & \\
\hline Coursework difficulty: Challenging & & $\begin{array}{c}0.981 \\
(0.690,1.396)\end{array}$ \\
\hline Coursework difficulty: Very Challenging & & $\begin{array}{c}1.268 \\
(0.717,2.245)\end{array}$ \\
\hline Class participation: Often & & $\begin{array}{c}1.088 \\
(0.771,1.536)\end{array}$ \\
\hline Class participation: Very Often & & $\begin{array}{c}2.053^{* * *} \\
(1.355,3.111)\end{array}$ \\
\hline Preparation for class (hrs/wk): 21-30 hrs & & $\begin{array}{c}0.785 \\
(0.535,1.151)\end{array}$ \\
\hline Preparation for class: $31+\mathrm{hrs}$ & & $\begin{array}{c}0.637^{* *} \\
(0.436,0.930)\end{array}$ \\
\hline Came to class unprepared: Sometimes & & $\begin{array}{c}1.265 \\
(0.836,1.915)\end{array}$ \\
\hline Came to class unprepared: Never & & $\begin{array}{c}1.622^{*} \\
(0.950,2.769)\end{array}$ \\
\hline Collaboration: Often/Very often & & $\begin{array}{c}1.269 \\
(0.922,1.748)\end{array}$ \\
\hline $\begin{array}{l}\text { Extracurricular legal experience (hrs/wk): } \\
1-10 \mathrm{hrs}\end{array}$ & & $\begin{array}{c}1.404^{*} \\
(0.940,2.096)\end{array}$ \\
\hline Extracurricular legal experience: $11-20 \mathrm{hrs}$ & & $\begin{array}{c}1.484^{*} \\
(0.973,2.263)\end{array}$ \\
\hline Extracurricular legal experience: $21+$ hrs & & $\begin{array}{c}1.415 \\
(0.911,2.198)\end{array}$ \\
\hline Self-Care (hrs/wk): $11-25 \mathrm{hrs}$ & & $\begin{array}{c}1.057 \\
(0.753,1.484)\end{array}$ \\
\hline Self-Care: $26+$ hrs & & $\begin{array}{c}1.369 \\
(0.817,2.292)\end{array}$ \\
\hline Other responsibilities (hrs/wk): 6-20 hrs & & $\begin{array}{c}0.899 \\
(0.637,1.268)\end{array}$ \\
\hline
\end{tabular}




\begin{tabular}{lccc}
\hline Other responsibilities: $21+$ hrs & & $0.630^{* *}$ \\
LSAT score & $1.817^{* * *}$ & $1.808^{* * *}$ & $(0.414,0.958)$ \\
& $(1.547,2.135)$ & $(1.529,2.137)$ & $(1.507,2.141)$ \\
UGPA & $1.510^{* * *}$ & $1.511^{* * * *}$ & $1.503^{* * *}$ \\
& $(1.307,1.745)$ & $(1.302,1.755)$ & $(1.291,1.751)$ \\
Asian & $0.472^{* * *}$ & $0.465^{* * *}$ & $0.604^{*}$ \\
& $(0.285,0.780)$ & $(0.273,0.791)$ & $(0.347,1.053)$ \\
Black & $0.564^{* *}$ & $0.503^{* *}$ & $0.554^{* *}$ \\
& $(0.329,0.966)$ & $(0.286,0.887)$ & $(0.314,0.976)$ \\
Hispanic & $0.560^{* * *}$ & $0.510^{* * *}$ & $0.611^{*}$ \\
& $(0.3543,0.887)$ & $(0.317,0.819)$ & $(0.372,1.004)$ \\
All Other Races & $0.245^{* * *}$ & $0.250^{* * *}$ & $0.330^{* *}$ \\
First Generation Law Student & $(0.107,0.561)$ & $(0.104,0.601)$ & $(0.130,0.841)$ \\
& & 1.069 & 1.179 \\
Amount of Law School Debt (control) & 0.974 & $(0.766,1.493)$ & $(0.826,1.680)$ \\
California Bar Takers & $(0.934,1.016)$ & & 0.980 \\
& 0.857 & 0.667 & $(0.937,1.025)$ \\
Log Likelihood & $(0.188,3.908)$ & $(0.149,2.997)$ & $(0.188,4.220)$ \\
Akaike Inf. Crit. & -557.560 & -532.530 & -497.985 \\
Bayesian Inf. Crit. & $1,147.121$ & $1,107.06$ & $1,045.971$ \\
\hline Note: & $1,227.486$ & $1,211.758$ & $1,170.192$ \\
\hline
\end{tabular}

Note: ${ }^{*} \mathrm{p}<0.10 ;{ }^{* *} \mathrm{p}<0.05 ;{ }^{* * *} \mathrm{p}<0.01 ;$ LSAT scores and UGPAs have been standardized within each school 
TABLE A.5

SUMMARY STATISTICS

\begin{tabular}{lcccccc}
\hline & Obs. & Mean & Median & St. Dev. & Min. & Max. \\
\hline Full Sample (N=4,722) & & & & & & \\
LSAT & 4,479 & 154.39 & 154.00 & 6.04 & 130.00 & 174.00 \\
UGPA & 4,602 & 3.30 & 3.36 & 0.40 & 1.82 & 4.17 \\
First-Semester LGPA & 4,313 & 3.10 & 3.13 & 0.47 & 1.16 & 4.29 \\
First-Year LGPA & 4,316 & 3.11 & 3.14 & 0.44 & 1.67 & 4.24 \\
Second-Year LGPA & 4,514 & 3.21 & 3.23 & 0.38 & 2.00 & 4.25 \\
Third-Year LGPA & 4,552 & 3.32 & 3.34 & 0.36 & 1.65 & 4.47 \\
Final LGPA & 4,684 & 3.27 & 3.28 & 0.36 & 2.04 & 4.23 \\
LGPA Growth & 4,313 & 0.17 & 0.15 & 0.26 & -0.86 & 1.79 \\
Bar Exam Result & 4,413 & 0.75 & - & - & - & - \\
LSSSE Respondents (N 2,025$)$ & & & & & & \\
LSAT & 1,977 & 154.53 & 155.00 & 6.21 & 130.00 & 172.00 \\
UGPA & 1,921 & 3.32 & 3.36 & 0.41 & 1.82 & 4.17 \\
First-Semester LGPA & 1,890 & 3.11 & 3.14 & 0.49 & 1.54 & 4.29 \\
First-Year LGPA & 1,892 & 3.12 & 3.15 & 0.46 & 1.67 & 4.24 \\
Second-Year LGPA & 1,966 & 3.23 & 3.24 & 0.39 & 2.00 & 4.25 \\
Third-Year LGPA & 1,979 & 3.33 & 3.35 & 0.36 & 2.06 & 4.38 \\
Final LGPA & 2,012 & 3.28 & 3.30 & 0.36 & 2.13 & 4.23 \\
LGPA Growth & 1,890 & 0.16 & 0.14 & 0.25 & -0.69 & 1.25 \\
Bar Exam Result & 1,922 & 0.75 & - & - & - & - \\
\hline
\end{tabular}

Note: Differences in means between the full sample and the LSSSE subsample are not statistically significant $(\mathrm{p}<$ 0.05 ); for bar passage, the difference in success rate was not statistically significant. 